Article

\title{
Assessment of Ag Nanoparticles Interaction over Low-Cost Mesoporous Silica in Deep Desulfurization of Diesel
}

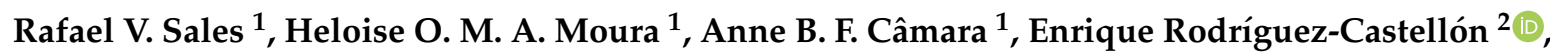 \\ José A. B. Silva ${ }^{1}$, Sibele B. C. Pergher ${ }^{1}$, Leila M. A. Campos ${ }^{3}$, Maritza M. Urbina ${ }^{4}$, \\ Tatiana C. Bicudo ${ }^{1}$ and Luciene S. de Carvalho ${ }^{1, *(D)}$ \\ 1 Energetic Technologies Research Group, Institute of Chemistry and School of Science and Technology, \\ Federal University of Rio Grande do Norte, Natal 59078-900, Brazil \\ 2 Dpto. de Química Inorgánica, Cristalografía y Mineralogía, Facultad de Ciencias, Universidad de Málaga, \\ 29071 Málaga, Spain \\ 3 Chemical Engineering Post-Graduate Program, Salvador University (UNIFACS), Salvador 40140-110, BA, \\ Brazil \\ 4 Chemical Engineering, Center for Technology, Federal University of Alagoas, Maceió 57072-900, AL, Brazil \\ * Correspondence: luciene_car@hotmail.com; Tel.: +55-849-8828-5261
}

Received: 5 July 2019; Accepted: 18 July 2019; Published: 30 July 2019

\begin{abstract}
Chemical interactions between metal particles (Ag or Ni) dispersed in a low-cost $\mathrm{MCM}-41^{\mathrm{M}}$ produced from beach sand amorphous silica and sulfur compounds were evaluated in the deep adsorptive desulfurization process of real diesel fuel. $\mathrm{N}_{2}$ adsorption-desorption isotherms, $\mathrm{X}$-ray diffraction (XRD), X-ray photoelectron spectroscopy (XPS), high-resolution transmission electron microscopy (HRTEM) and scanning transmission electron microscopy coupled to energy-dispersive X-ray spectroscopy (STEM-EDX) were used for characterizing the adsorbents. HRTEM and XPS confirmed the high dispersion of Ag nanoparticles on the MCM-41 surface, and its chemical interaction with support and sulfur compounds by diverse mechanisms such as $\pi$-complexation and oxidation. Thermodynamic tests indicated that the adsorption of sulfur compounds over $\mathrm{Ag}(\mathrm{I}) / \mathrm{MCM}-41^{\mathrm{M}}$ is an endothermic process under the studied conditions. The magnitude of $\Delta \mathrm{H}^{\circ}(42.1 \mathrm{~kJ} / \mathrm{mol})$ indicates that chemisorptive mechanisms govern the sulfur removal. The best fit of kinetic and equilibrium data to pseudo-second order $\left(R^{2}>0.99\right)$ and Langmuir models $\left(R^{2}>0.98\right)$, respectively, along with the results for intraparticle diffusion and Boyd's film-diffusion kinetic models, suggest that the chemisorptive interaction between organosulfur compounds and Ag nanosites controls sulfur adsorption, as seen in the XPS results. Its adsorption capacity $\left(q_{\mathrm{m}}=31.25 \mathrm{mgS} / \mathrm{g}\right)$ was 10 times higher than that obtained for pure MCM- $41^{\mathrm{M}}$ and double the $q_{\mathrm{m}}$ for the $\mathrm{Ag}(\mathrm{I}) / \mathrm{MCM}-41^{\mathrm{C}}$ adsorbent from commercial silica. Saturated adsorbents presented a satisfactory regeneration rate after a total of five sulfur adsorption cycles.
\end{abstract}

Keywords: desulfurization; chemisorption; MPI silica; MCM-41; Ag nanoparticles; XPS assessment

\section{Introduction}

The demand for clean energy has attracted great attention in recent years and has generated an increasing focus on sulfur compounds removal from fuels [1]. The combustion of these compounds results in liberating sulfur oxides $\left(\mathrm{SO}_{\mathrm{x}}\right)$, which poison catalytic converters and are corrosive to fuel cell electrodes [2], in addition to polluting the environment; therefore, governments worldwide have adopted standards to decrease sulfur concentration to $10 \mathrm{ppm}$ for diesel fuel [3]. The current technique for sulfur removal in oil refineries is the highly expensive hydrodesulfurization (HDS), performed 
at hard conditions $\left(>573 \mathrm{~K},>4 \mathrm{MPa}\right.$ ) using sophisticated $\mathrm{Co}-\mathrm{Mo} / \mathrm{Al}_{2} \mathrm{O}_{3}$ or $\mathrm{Ni}-\mathrm{Mo} / \mathrm{Al}_{2} \mathrm{O}_{3}$ catalysts. However, some recalcitrant organosulfur such as thiophene derivatives are not removed by this method [4].

Methods based on membrane separation [5], catalytic oxidation [3], biological desulfurization [6], and adsorption [1,7-11] have been developed for desulfurizing fuels. Among these techniques, adsorptive desulfurization stands out due to its simplicity, efficiency and low-cost according to the solid chosen as the adsorbent. Activated carbon [1], MOFs [9], KIT-6 [10], SBA-15 [8], and MCM-41 [7,11] are currently being investigated for sulfur adsorption from liquid fuels, among other materials.

These molecular sieves, especially MCM-41, are extensively applied as supports for adsorbents and heterogeneous catalysts due to their high surface area, ordered structure, and uniform pore size [12]. In general, heterogeneous micrometric size catalysts present low catalytic activity due to slow diffusion of reagents [13]. Therefore, active metal nanoparticles (NPs), which have high catalytic activity due to their high surface-volume ratio and chemical reactivity, have been incorporated into solid supports for increasing their efficiency, recyclability and stability, thus providing more sustainable processes [14-16]. When unsupported, the high surface energy of nanocatalysts increases system instability and leads to aggregation, thus resulting in the loss of its catalytic properties. The use of molecular sieve supports is fundamental to prevent the undesirable aggregation and loss of nanocatalysts $[17,18]$.

Moreover, MCM-41 has gained attention for its flexibility regarding the silica feedstock for synthesis. Recently, it has been produced from greener sources of silica such as coal fly ash (CFA) [12], rice husk ash [19], iron ore residues [20], wheat stem ash (WSA) [21], and MPI silica from beach sand [22,23], used in this study. This material has been functionalized by adding active sites to its surface for promoting new chemical interactions in the support-site-adsorbate system and improving the adsorptive treatment [24]. Researchers have observed that adsorbents functionalized with transition metals are capable of capturing aromatic sulfur compounds refractory to HDS processes via $\pi$-complexation $[25,26]$. Furthermore, Ag species dispersed onto metal and semi-metal oxide adsorbents generate materials described as high activity catalysts for oxidation of several toxic compounds such as formaldehyde [27], benzene [28], toluene [29] and carbon monoxide [24], among others.

The $\mathrm{Ag}(0)$ sites present high reactivity both by adsorbing and activating atmospheric $\mathrm{O}_{2}$ at ambient conditions (300 K, $1 \mathrm{~atm}$ ) [30] and by increasing the mobility of lattice oxygens from the adsorbent structure. This increase in mobility can occur by bridging bonds between $\operatorname{Ag}(0)$ and the metal oxide molecules [28], but it is also reported by covalent bonding in the case of a more oxidized state of silver as $\mathrm{Ag}(\mathrm{I})$, and in a cation exchange of hydrolyzed silica silanol groups (Si-O-H) [31]. Thus, an instrumental technique such as X-ray photoemission spectroscopy (XPS) is required to identify the chemical species in the sample and to indicate what kind of interactions could be involved in impregnation and chemisorptions processes. This analysis is able to capture chemical changes in the adsorbent surface after metal deposition and adsorption by recording displacements in binding energies of the atoms and ions involved in the mechanisms [32].

This paper proposes a low-cost method for mitigating sulfur content in diesel fuel based on the adsorption of organosulfur compounds over Ag and Ni impregnated MCM-41 supports from beach sand silica, in a complementary process to the hydrodesulfurzation (HDS) applied in refineries with a greener and effective approach. Furthermore, high-efficiency characterization techniques such as X-ray photoelectron spectroscopy (XPS) and high-resolution transmission electron microscopy (HRTEM) were used to enable the more accurate analysis of the different species and interaction mechanisms in the metal-support-organosulfur system, and were associated with a deep evaluation of the kinetic and thermodynamic features. 


\section{Results and Discussion}

\subsection{Preliminary Sulfur Adsorption Results}

The results of sulfur adsorption in columns for $\mathrm{AgNO}_{3} / \mathrm{MCM}-41$ produced from both MPI and commercial silicas interacted more strongly with organosulfur compounds and reached higher desulfurization results. The adsorbent generated from MPI silica presented lower performance in comparison to the commercial material; however, its efficiency is significant and it stands out for being extracted from a renewable and low-cost source. There was no relevant variation in adsorption by changing metal concentration from $2 \%$ to $8 \%$. Taking into consideration the performance and cost-benefits, the concentration of $2 \%$ salts in $\mathrm{MCM}-41^{\mathrm{M}}$ was selected for the next steps of characterization and adsorption studies. The sulfur adsorption results for all materials applied in this research are depicted in Figure S1 of the Supplementary Materials. The XRD patterns for the adsorbents with $8 \%$ metal (Ni or $\mathrm{Ag}$ ) in salt and oxide forms are presented in Figure S2 of the Supplementary Materials.

\subsection{Characterization of the Adsorbents}

Low-angle XRD patterns of the samples are shown in Figure 1a. The presence of diffraction peaks indexed by (100), (110) and (200) confirms the well-ordered structure with hexagonal p6mm symmetry, indicating a relative perfect structure of MCM-41 samples [33]. Less ordered materials were obtained after impregnation; however, the deposition of transition metals in the adsorbent via wet impregnation did not compromise the ordered porous structure of $\mathrm{MCM}-41^{\mathrm{M}}$.
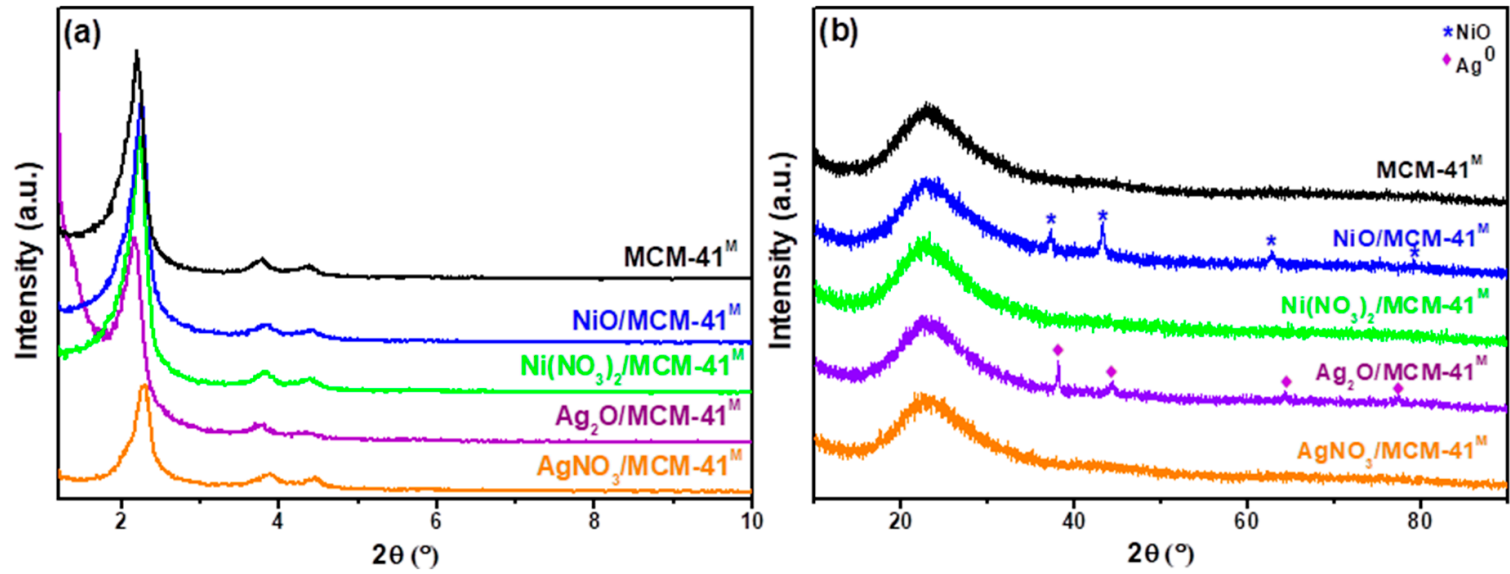

Figure 1. (a) Low-angle and (b) wide-angle X-ray diffractograms of the adsorbents.

Wide-angle XRD patterns of all samples (Figure 1b) exhibited broad diffraction peaks centered at $22.8^{\circ}$, originated from amorphous silica (MPI silica). $\mathrm{AgNO}_{3} / \mathrm{MCM}-41^{\mathrm{M}}$ and Ni(NO$)_{2} / \mathrm{MCM}^{\mathrm{M}}-41^{\mathrm{M}}$ adsorbents have not shown any reflection referent to deposited species, supporting the idea that they are highly dispersed and have a high interaction with the mesoporous support [34]. Refraction peaks corresponding to the cubic phase of $\mathrm{NiO}$ at $2 \theta$ of 37.16, 43.31, 62.88 and 79.31 (JCPDS 01-073-1523) and the face-centered-cubic (FCC) phase from metallic Ag at $2 \theta$ of 38.16, 44.30, 64.30 and 77.44 (JCPDS 04-0783) were detected in $\mathrm{NiO} / \mathrm{MCM}-41^{\mathrm{M}}$ and $\mathrm{Ag}_{2} \mathrm{O} / \mathrm{MCM}-41^{\mathrm{M}}$, respectively (Figure $1 \mathrm{~b}$ ).

HRTEM micrographs for pure MCM- $41^{\mathrm{M}}$ (Figure 2a,b) confirm the hexagonal high-organized pore matrix, typical of this material, as seen in XRD patterns [35]. The $\mathrm{AgNO}_{3} / \mathrm{MCM}-41^{\mathrm{M}}$ sample was analyzed by STEM-EDX mapping images and HRTEM. The STEM-EDX mapping profile for deposited species (Figure 2c-e) shows highly uniform distribution of silver nanoparticles (red spots), with some agglomerations, and silica particles were also observed in green. According to a HRTEM micrograph (Figure 2f), the MCM-41 ${ }^{\mathrm{M}}$ mesostructure was preserved after its modification with $\mathrm{Ag}^{+}$ions. 

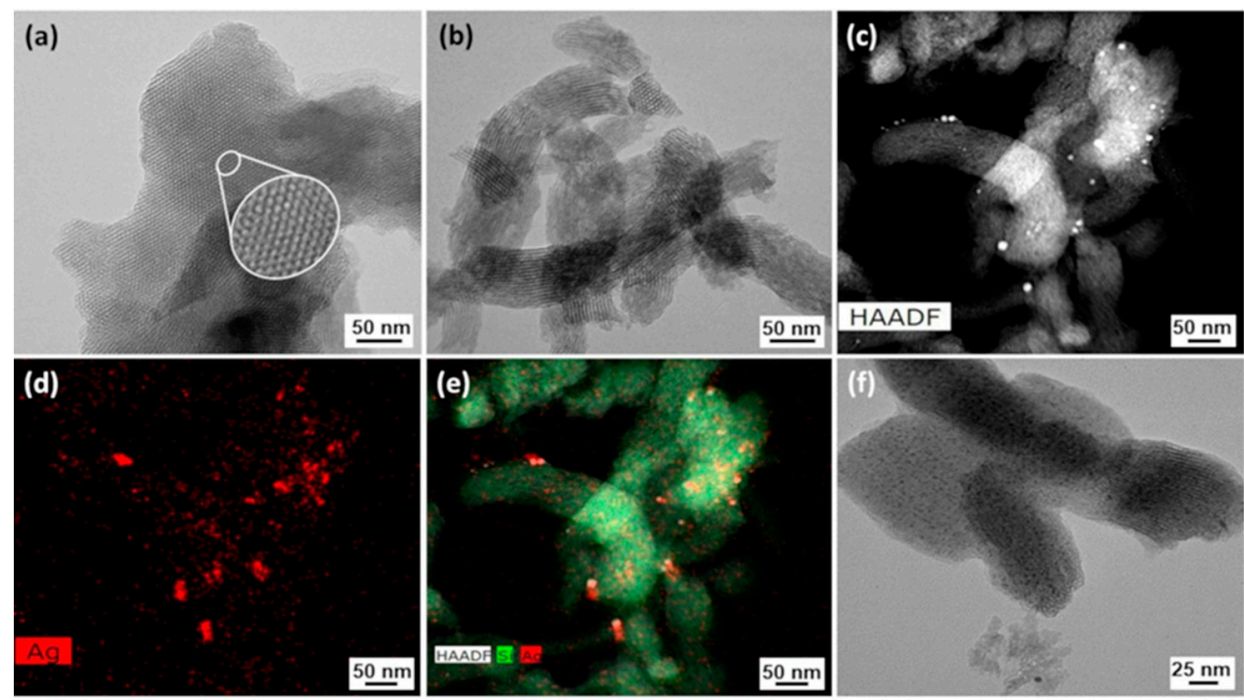

Figure 2. (a,b) HRTEM micrograph for pure MCM-41 ${ }^{\mathrm{M}}$; (c) STEM, (d) EDX, (e) STEM-EDX and (f) HRTEM analysis for $\mathrm{AgNO}_{3} / \mathrm{MCM}-41^{\mathrm{M}}$.

The $\mathrm{N}_{2}$ adsorption-desorption isotherms and pore size distribution are depicted in Figure 3. The isotherms for all the samples are type IV according to the IUPAC classification, which is characteristic of MCM-41 [36]. As depicted in Figure 3a, the $\mathrm{N}_{2}$ adsorption-desorption isotherms for all the samples were correspondent to type IV according to the IUPAC classification, which is associated to mesoporous materials with $\mathrm{H} 3$-type hysteresis loop due to capillary condensation [34]. The adsorption-desorption in intermediary relative pressures $\left(0.3<\mathrm{P} / \mathrm{P}_{0}<0.4\right)$ correspond to $\mathrm{N}_{2}$ capillary condensation of uniform mesopores. The metal incorporation to the mesoporous sieve has not affected the isotherms profile. A slight inflection for the $\mathrm{Ag}_{2} \mathrm{O} / \mathrm{MCM}-41^{\mathrm{M}}$ sample can be noticed, which suggests a less-organized mesoporous structure [11], as observed in the XRD data shown in Figure 1a. All samples presented an increase in adsorbed volume due to the macropore filling resulting from interparticle spaces and untransformed amorphous silica in the relative pressure range 0.90-0.99 [35].
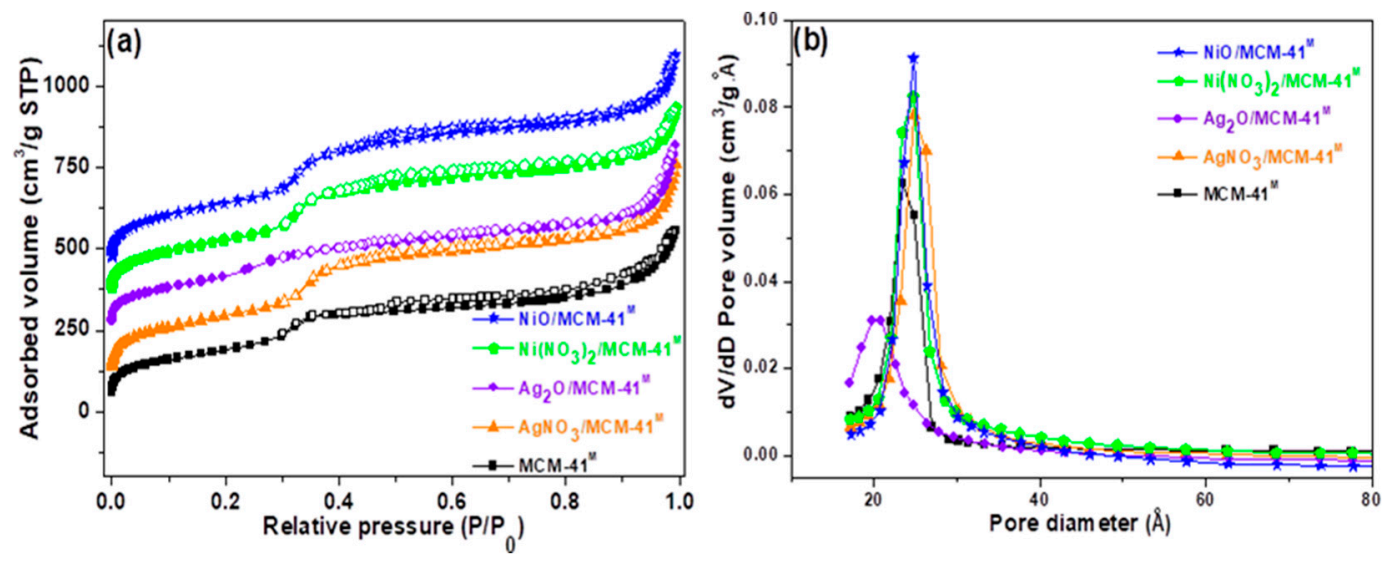

Figure 3. (a) $\mathrm{N}_{2}$ adsorption-desorption isotherms at $77 \mathrm{~K}$ (b) and the corresponding BJH adsorption pore size distributions for the adsorbents.

The pore size distribution (Figure $3 \mathrm{~b}$ ) estimated by the $\mathrm{BJH}$ method indicates that the materials have uniform mesoporosity with a maximum distribution in the range of 23.54-24.82 $\AA$. An exception was the $\mathrm{Ag}_{2} \mathrm{O} / \mathrm{MCM}-41^{\mathrm{M}}$ sample, which exhibited a smaller maximum pore size centered at about $20.20 \AA$ and heterogeneous distribution [4]. In this case, $\mathrm{Ag}_{2} \mathrm{O}$ species are possibly deposited inside the pores, while the species were preferentially deposited outside the pore system for the other materials. 
Textural parameters of the adsorbents are listed in Table 1 and presented a reduction in specific area $\left(\mathrm{S}_{\mathrm{BET}}\right)$ and pore volume $\left(\mathrm{V}_{\mathrm{P}}\right)$ compared to the initial silica material, indicating that the deposited particles caused the occlusion of some pores, reducing the amount of adsorbed $\mathrm{N}_{2}$. In addition, the embedded species are not porous, which reduces porosity and consequently the specific area of the materials [37].

Table 1. Textural properties of the studied samples.

\begin{tabular}{cccc}
\hline Adsorbent & $\mathbf{S}_{\text {BET }}{ }^{\mathbf{1}}\left(\mathbf{m}^{\mathbf{2}} / \mathbf{g}\right)$ & $\mathbf{V}_{\mathbf{P}}{ }^{\mathbf{2}}\left(\mathbf{c m}^{\mathbf{3}} / \mathbf{g}\right)$ & Maximun Pore Diameter (̊) \\
\hline $\mathrm{MCM}-41^{\mathrm{M}}$ & 722 & 0.79 & 23.54 \\
$\mathrm{AgNO}_{3} / \mathrm{MCM}-41^{\mathrm{M}}$ & 656 & 0.74 & 24.82 \\
$\mathrm{Ag}_{2} \mathrm{O} / \mathrm{MCM}-41^{\mathrm{M}}$ & 704 & 0.71 & 20.20 \\
$\mathrm{Ni}\left(\mathrm{NO}_{3}\right)_{2} / \mathrm{MCM}-41^{\mathrm{M}}$ & 641 & 0.57 & 24.70 \\
$\mathrm{NiO} / \mathrm{MCM}-41^{\mathrm{M}}$ & 703 & 0.71 & 24.75 \\
\hline
\end{tabular}

${ }^{1}$ Specific surface area calculated by the BET method. ${ }^{2}$ Total pore volume recorded at $\mathrm{P} / \mathrm{P}_{0}=0.993$.

XPS analysis was employed to obtain information about the surface composition, species identification and chemical state of the transition metal over $\mathrm{MCM}-41^{\mathrm{M}}$ surface. The XPS spectrum of the pure MCM- $41^{\mathrm{M}}$ sample is shown in Figure 4. The binding energy (BE) of the Si $2 p$ orbital in all the samples was about $103.3 \mathrm{eV}$, which is characteristic of mesoporous silicates such as MCM-41. Additionally, a single peak centered at $532.7 \mathrm{eV}$ would be assigned to the $\mathrm{O} 1 \mathrm{~s}$ photoemission of oxygen atoms from the siliceous support [38].

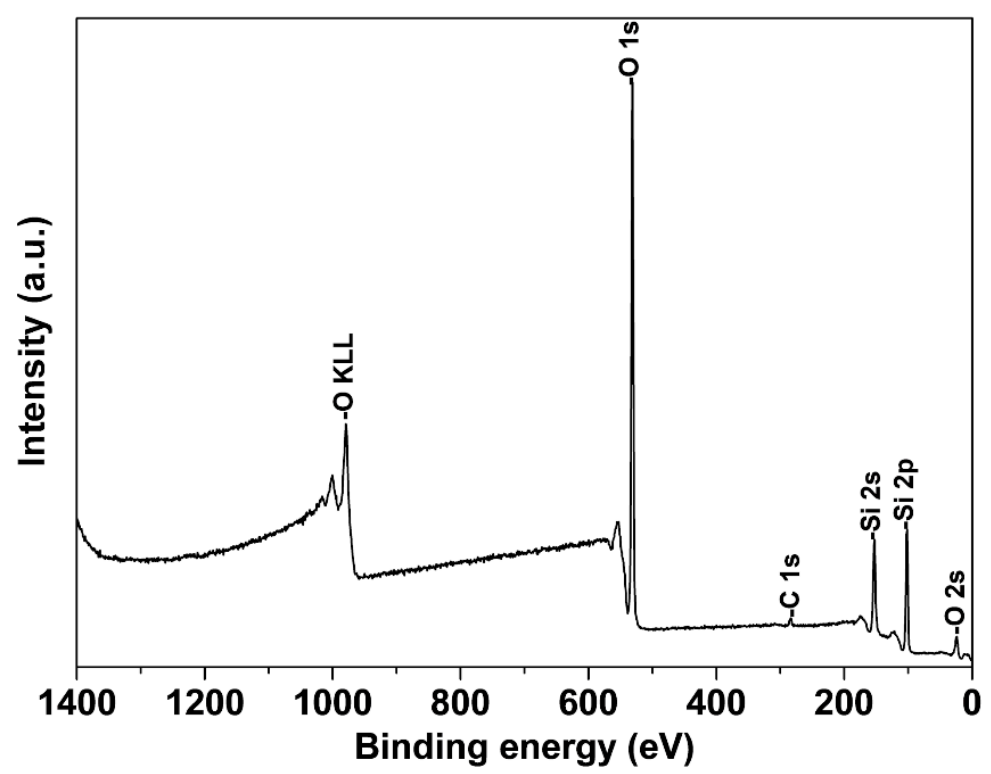

Figure 4. XPS spectra for pure MCM- $41^{\mathrm{M}}$.

For $\mathrm{AgNO}_{3} / \mathrm{MCM}-41^{\mathrm{M}}$ (Figure $5 \mathrm{a}$ ), broad peaks in between the characteristic BE for Ag(I) species (367.5 and $373.8 \mathrm{eV}$ ) and $\mathrm{Ag}(0)$ nanoparticles (369.7 and $375.9 \mathrm{eV}$ ) are observed for the $\mathrm{Ag} 3 \mathrm{~d}_{5 / 2}$ and $3 \mathrm{~d}_{3 / 2}$ orbitals at 368.1 and $374.1 \mathrm{eV}$, respectively [39]. This phenomenon suggests the interaction of impregnated $\mathrm{AgNO}_{3} \mathrm{Ag}(\mathrm{I})$ ions with other atoms such as adsorbed atmospheric oxygen (Ag- $\mathrm{O}_{\text {ads }}$ ), lattice oxygen $\left(\mathrm{Ag}-\mathrm{O}_{\text {lat }}\right.$ ) and silanol groups $(\mathrm{Ag}-\mathrm{O}-\mathrm{Si})$ of $\mathrm{MCM}-41^{\mathrm{M}}$, now presenting a $\mathrm{BE}$ state in between the ionic and metallic forms $\left(\mathrm{Ag}^{\delta+}, 0<\delta<1\right)[31,40]$. 

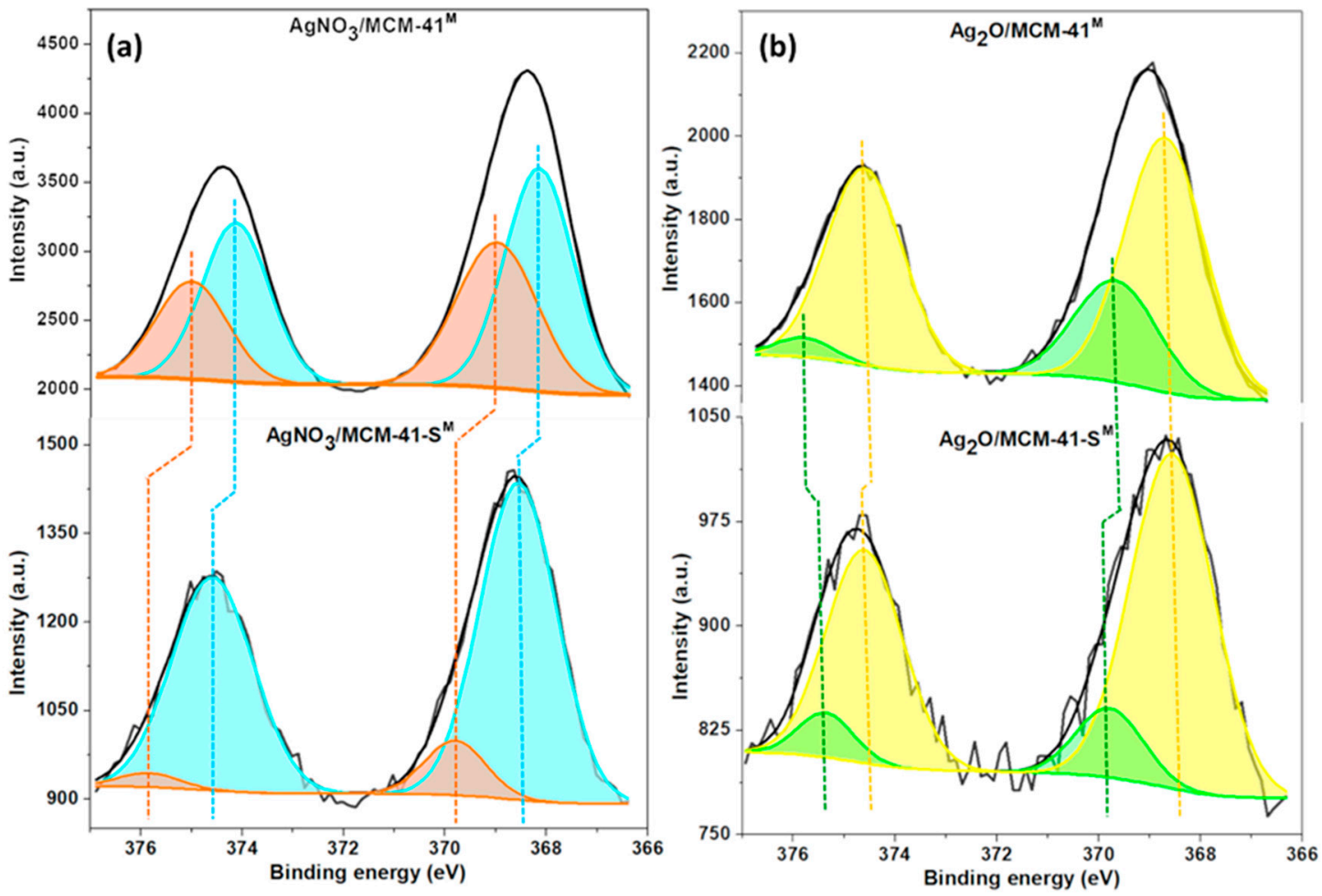

Figure 5. XPS spectra for (a) $\mathrm{AgNO}_{3} / \mathrm{MCM}-41^{\mathrm{M}}$ and (b) $\mathrm{Ag}_{2} \mathrm{O} / \mathrm{MCM}-41^{\mathrm{M}}$ before and after desulfurization.

Smaller peaks at 369.0 and $375.0 \mathrm{eV}$ are assigned to the typical $\mathrm{BE}$ region for $\mathrm{Ag}(0)$ nanoparticles highly dispersed in the support [30,41]. The presence of the metallic electronic state of silver may be related to the photolysis of the $\mathrm{AgNO}_{3}$ molecule in the presence of light; furthermore, it is known in the literature that some oxygenated metal-adsorbents can undergo autoreduction processes in the presence of lattice oxygen and water [42]. $\mathrm{Ag}(0)$ can also interact with oxygen ( $\mathrm{Ag}-\mathrm{O}_{\mathrm{ads}}$ and $\left.\mathrm{Ag}-\mathrm{O}_{\text {lat }}\right)$. All these oxygenated species (Ag-O) are highly active for oxidation of aromatic pollutants [34] and even for weak $\pi$-complexation interactions with aromatic organosulfurs, as well as the non-bonding $\mathrm{Ag}(0)$ nanodomains [36].

After sulfur adsorption was performed with model diesel, the displacement to higher BE values indicates more positive electronic density of $\mathrm{Ag}$ species [27]. The increase in BEs of oxygenated Ag species (368.4 and $374.5 \mathrm{eV}$ ) can be assigned to oxygen loss after oxidation reactions, while the broad peaks which emerged at 369.4 and $375.6 \mathrm{eV}$ are ascribed to the formation of an Ag-S-R bridging configuration via $\pi$-complexation ( $\mathrm{S}-\mathrm{R}=\mathrm{DBT}$ ) performed by $\mathrm{Ag}(0)$ and also by active $\mathrm{Ag}-\mathrm{O}$ species [26,43]. In this mechanism, $\mathrm{Ag}(0)\left([\mathrm{Kr}] 4 \mathrm{~d}^{10} 5 \mathrm{~s}^{1}\right)$ and $\mathrm{Ag}(\mathrm{I})\left([\mathrm{Kr}] 4 \mathrm{~d}^{10} 5 \mathrm{~s}^{0}\right)$ species are able to form bonds with their empty or semi-filled $s$ orbitals and their $d$ orbitals can retrograde electronic density to the $\pi$ anti-ligands ( $\pi^{*}$ ) of aromatic organosulfur rings [25].

For the sample that was calcined in an oxidizing atmosphere, the XPS spectra (Figure 5b) show broad peaks at 368.5 and $374.6 \mathrm{eV}$, which can be ascribed to the production of stable $\mathrm{Ag}_{2} \mathrm{O}$ species that can emerge in this BE region [44]; since the spectral resolution for all XPS analysis was $0.8 \mathrm{eV}$, significant peak separation was not possible. Highly dispersed Ag nanodomains were also observed at 369.4 and $375.9 \mathrm{eV}$. The spectra recorded after this material was used for desulfurization shows that the $\mathrm{Ag}_{2} \mathrm{O} / \mathrm{Ag}$-O peak BE remained almost unchanged; however, the increase in $\mathrm{Ag}(0) \mathrm{BE}$ (369.8 and $375.4 \mathrm{eV}$ ) demonstrates the same phenomenon observed for the non-calcined sample, where metallic and active silver species were complexed by DBT molecules.

The atomic concentrations in the adsorbents surface were measured by the XPS technique and are summarized in Table 2. Ni, C, O and Si contents in $\mathrm{Ni}\left(\mathrm{NO}_{3}\right)_{2} / \mathrm{MCM}-41^{\mathrm{M}}$ and $\mathrm{NiO} / \mathrm{MCM}-41^{\mathrm{M}}$ adsorbents were similar; however, the Ag-impregnated sample after calcination presented some 
significant variations in the atomic concentrations, with a increase in the $C$ atomic percentage. As the penetration depth of XPS radiation is about $10 \mathrm{~nm}$ [44], X-rays are only able to reach the atoms near the surface, and the higher amount of carbon in this region promotes a decrease in other atoms concentrations, as seen for silver and oxygen. The $\mathrm{AgNO}_{3} / \mathrm{MCM}-41^{\mathrm{M}}$ adsorbent presented higher sulfur concentrations after adsorption tests among all samples.

Table 2. Atomic concentrations (\%) in the adsorbents surface and Si/metal molar ratio.

\begin{tabular}{|c|c|c|c|c|c|c|c|c|}
\hline \multirow[t]{2}{*}{ Samples } & \multicolumn{5}{|c|}{ Atomic Concentrations (\%) } & \multicolumn{2}{|c|}{ Molar Ratios } & \multirow{2}{*}{$\begin{array}{c}\text { After Desulfurization (\%) } \\
\mathrm{S} 2 p\end{array}$} \\
\hline & C $1 s$ & O 1s & Si $2 p$ & $\operatorname{Ag} 3 d$ & Ni $2 p$ & $\mathrm{Si} / \mathrm{Ag}$ & $\mathrm{Si} / \mathrm{Ni}$ & \\
\hline $\mathrm{MCM}-41^{\mathrm{M}}$ & 2.24 & 69.59 & 28.18 & & & & & \\
\hline $\mathrm{AgNO}_{3} / \mathrm{MCM}-41^{\mathrm{M}}$ & 1.94 & 68.05 & 29.34 & 0.67 & & 43.79 & & 1.87 \\
\hline $\mathrm{Ag}_{2} \mathrm{O} / \mathrm{MCM}-41^{\mathrm{M}}$ & 5.66 & 64.58 & 29.43 & 0.32 & & 91.97 & & 1.78 \\
\hline $\mathrm{Ni}\left(\mathrm{NO}_{3}\right)_{2} / \mathrm{MCM}-41^{\mathrm{M}}$ & 4.75 & 66.27 & 26.38 & & 0.54 & & 48.85 & 1.62 \\
\hline $\mathrm{NiO} / \mathrm{MCM}-41^{\mathrm{M}}$ & 3.75 & 67.10 & 26.94 & & 0.56 & & 48.10 & 1.64 \\
\hline
\end{tabular}

\subsection{Kinetic Study}

Sulfur adsorption rate performed with real diesel on $\mathrm{AgNO}_{3} / \mathrm{MCM}-41^{\mathrm{M}}$ and pure $\mathrm{MCM}-41^{\mathrm{M}}$ was determined via kinetic analysis. Contact time effect data presented in Figure 6a show that the organosulfur contaminants were rapidly adsorbed by $\mathrm{AgNO}_{3} / \mathrm{MCM}-41^{\mathrm{M}}$ (about 5 min of contact) and reached equilibrium in approximately $120 \mathrm{~min}$. No significant adsorption of these compounds was observed after $5 \mathrm{~min}$ for the pure MCM- $41^{\mathrm{M}}$, which may be related to the fewer available active sites [45]. Figure 6 shows the fitting and Table 3 brings the summary of the corresponding adsorption parameters and determination coefficients $\left(R^{2}\right)$.

Table 3. Kinetic parameters fitted to pseudo-first order, pseudo-second order, Elovich, intraparticle diffusion and Boyd models. Experimental conditions: room temperature and pressure, 500 ppm sulfur real diesel.

\begin{tabular}{|c|c|c|c|c|c|c|c|c|c|c|c|}
\hline \multirow[b]{2}{*}{ Adsorbent } & \multirow{2}{*}{$\begin{array}{l}q_{e}, \exp \\
(\mathrm{mg} / \mathrm{g})\end{array}$} & \multicolumn{4}{|c|}{ Pseudo-First Order } & & \multicolumn{5}{|c|}{ Pseudo-Second Order } \\
\hline & & \multicolumn{2}{|l|}{$\begin{array}{c}k_{1} \\
\left(\min ^{-1}\right)\end{array}$} & $\begin{array}{l}q_{e}, \mathrm{cal} \\
(\mathrm{mg} / \mathrm{g})\end{array}$ & $\mathrm{R}^{2}$ & & \multicolumn{2}{|c|}{$k_{2}(\mathrm{~g} /(\mathrm{mg} \min ))$} & $\begin{array}{l}q_{e}, \mathrm{cal} \\
(\mathrm{mg} / \mathrm{g})\end{array}$ & \multicolumn{2}{|c|}{$\mathbf{R}^{2}$} \\
\hline $\mathrm{AgNO}_{3} / \mathrm{MCM}-41^{\mathrm{M}}$ & 7.26 & \multicolumn{2}{|l|}{0.005} & 2.05 & 0.814 & & \multicolumn{2}{|c|}{0.010} & 7.31 & \multicolumn{2}{|c|}{0.998} \\
\hline $\mathrm{MCM}-41^{\mathrm{M}}$ & 1.64 & 0.002 & & 0.79 & 0.516 & & \multicolumn{2}{|c|}{0.013} & 1.60 & \multicolumn{2}{|c|}{0.890} \\
\hline \multirow[b]{2}{*}{ Adsorbent } & & \multicolumn{3}{|c|}{ Elovich Model } & & \multicolumn{3}{|c|}{ Intraparticle Diffusion } & & \multicolumn{2}{|c|}{ Boyd } \\
\hline & & $\begin{array}{c}\alpha \\
(\mathrm{mg} / \mathrm{g} \min )\end{array}$ & $\begin{array}{c}\beta \\
(\mathrm{g} / \mathrm{mg})\end{array}$ & $\mathbf{R}^{2}$ & & $\begin{array}{c}k_{i d} \\
(\mathrm{mg} /(\mathrm{g} \text { min }))\end{array}$ & $\begin{array}{c}C \\
(\mathrm{mg} / \mathrm{g})\end{array}$ & $\mathbf{R}^{2}$ & & $B^{1}$ & $\mathbf{R}^{2}$ \\
\hline $\mathrm{AgNO}_{3} / \mathrm{MCM}-41^{\mathrm{M}}$ & & 45.257 & 1.426 & 0.977 & & 0.126 & 4.654 & 0.894 & & 0.007 & 0.977 \\
\hline $\mathrm{MCM}-41^{\mathrm{M}}$ & & 0.786 & 5.432 & 0.710 & & 0.034 & 0.709 & 0.691 & & 0.771 & 0.710 \\
\hline
\end{tabular}

Experimental results of sulfur removal on $\mathrm{AgNO}_{3} / \mathrm{MCM}-41^{\mathrm{M}}$ adsorbent were better fitted to the pseudo-second order model, with $\mathrm{R}^{2}>0.99$ and similar calculated and experimental $q_{e}$ values $\left(7.31 \mathrm{mg} / \mathrm{g}\right.$ and $7.26 \mathrm{mg} / \mathrm{g}$, respectively), followed by Elovich $\left(\mathrm{R}^{2}=0.977\right)$ and pseudo-first order $\left(\mathrm{R}^{2}=\right.$ 0.814 ) models, respectively. The best data fitting to the pseudo-second order and Elovich models is a clue that the chemisorption process is the rate determining step of adsorption [46]. Furthermore, the higher value of parameter $\alpha$ obtained by Elovich equation (Table 3 ) suggests that there is a strong affinity between the recalcitrant compounds containing $\mathrm{S}$ and the active sites of $\mathrm{AgNO}_{3} / \mathrm{MCM}-41^{\mathrm{M}}$ adsorbent, strengthening the hypothesis that this adsorption is highly influenced by $\mathrm{Ag}$ sites and its different active forms $(\mathrm{Ag}(0)$ and $\mathrm{Ag}-\mathrm{O})$, and mainly occurs via $\pi$-complexation and oxidation $[47,48]$. The slower adsorption rate after the initial minutes may be a reflection of concurrent kinetic mechanisms [46]. For pure MCM- $41^{\mathrm{M}}$, the experimental results were better fitted to the pseudo-second order model, with $\mathrm{R}^{2}$ $>0.89$ and calculated $q_{e}(1.60 \mathrm{mg} / \mathrm{g})$ close to the experimental result $(1.64 \mathrm{mg} / \mathrm{g})$. Low $\mathrm{R}^{2}$ values indicate that the pseudo-first-order and Elovich kinetic models did not adequately describe the adsorption process performed by this sample. 

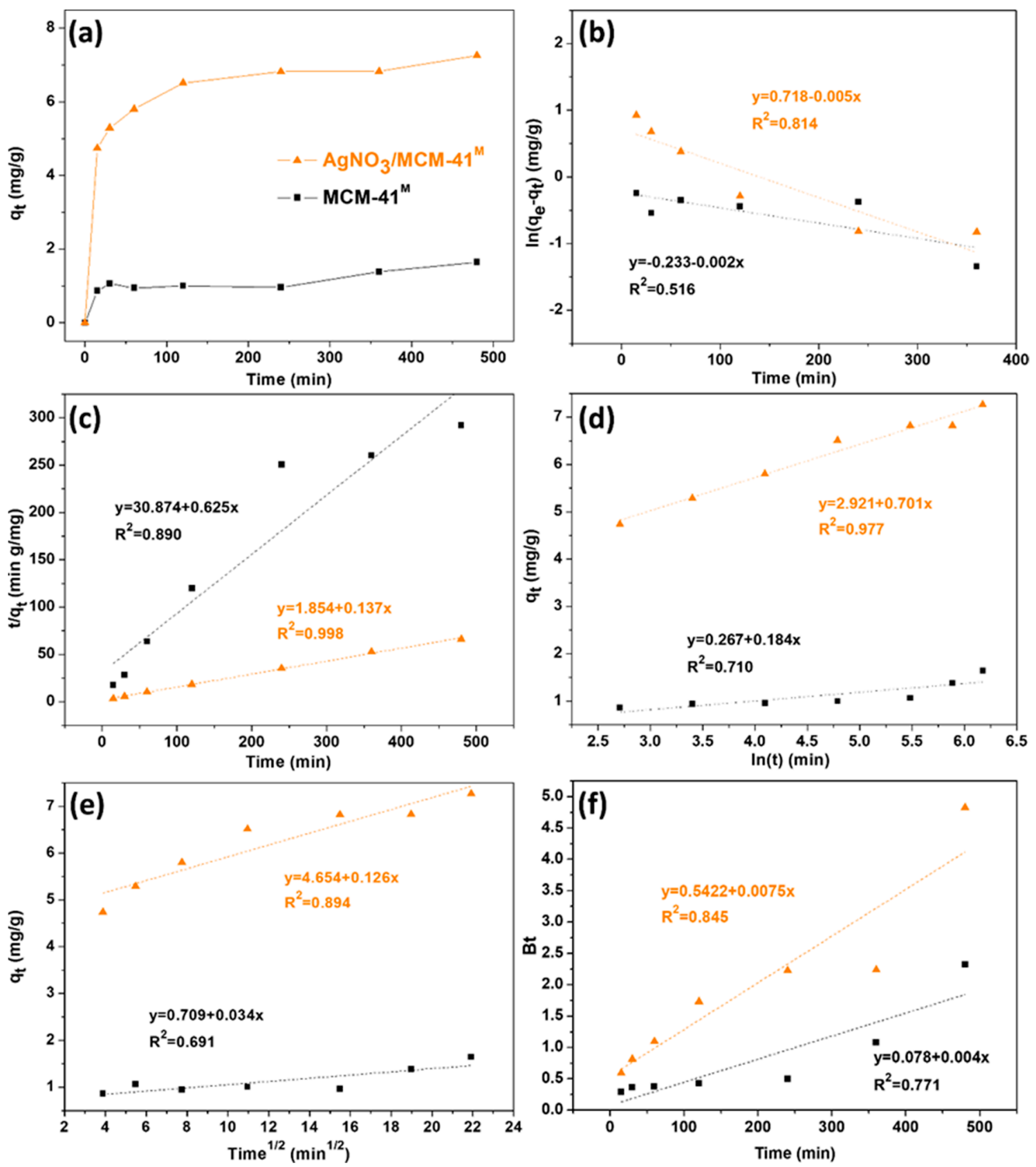

Figure 6. Plots of (a) contact time effect, (b) pseudo-first order, (c) pseudo-second order, (d) Elovich, (e) intraparticle diffusion and (f) Boyd models, where $\Delta$ represents the kinetic data obtained for $\operatorname{AgMCM}-41^{\mathrm{M}}$ and $\mathbf{m}$ represents the kinetic data obtained for $\mathrm{MCM}-41^{\mathrm{M}}$.

Considering molecular structures, critical diameters of sulfur compounds in model diesel are smaller than those in commercial diesel [49], whose main composition is listed in Table S1 of the Supplementary Materials. Thus, performing desulfurization tests with the real fuel is the best way to evaluate the performance of the adsorbents. For the effective adsorption of larger molecules in terms of physisorption, not only should the pore size of the material be at least larger than the critical diameter of the adsorbate, but it should also be large enough to reduce diffusional resistance during adsorption [50]. Therefore, the high sulfur adsorption performed by $\mathrm{AgNO}_{3} / \mathrm{MCM}-41$ can also be related to its larger pore diameter $(24.82 \AA)$ in relation to the other synthesized impregnated materials (as shown in Table 1 ), favoring adsorption due to both the more effective reduction of the diffusional resistance of aromatic 
organosulfurs (whose critical diameters are shown in Table S2 of the Supplementary Materials) and the stronger chemical interactions promoted by the more active Ag species over this adsorbent.

This fact can be verified by the results of intraparticle diffusion and film diffusion of Boyd models. Since the data fitting curves for intraparticle diffusion did not cross the axes origin (Figure 6e), it can be assumed that intrapore diffusion is not the limiting step of the adsorption process, and therefore other mechanisms must be acting simultaneously. This is confirmed by the Boyd model (Figure $6 \mathrm{f}$ ), since the graphs have non-zero intercepts. The non-linearity of Boyd model graphs indicates that pore diffusion is not the rate control step and that there is a mass transfer resistance step in the outer film [51]. Thus, although both intraparticle diffusion and film diffusion are involved in the adsorptive process, these physical phenomena do not govern desulfurization.

\subsection{Adsorption Equilibrium Isotherms}

Langmuir, Freundlich, Temkin, and Dubinin-Radushkevich equations were used to fit the experimental sulfur adsorption results with real diesel. The isotherm parameters and the correlation coefficients $\left(R^{2}\right)$ obtained from the linear fitting of experimental data are summarized in Table 4 . The non-linear adjustments and variations in the separation factor $\left(R_{L}\right)$ as a function of initial sulfur concentration $\left(C_{0}\right)$ are displayed in Figures 7 and 8 , respectively. Based on $R^{2}$ values, Langmuir and Freundlich mathematical models show good fitting to the adsorption equilibrium data for all the studied adsorbents. Experimental adsorption results for $\mathrm{MCM}-41^{\mathrm{M}}$ were better adjusted to the Freundlich model $\left(R^{2}=0.9904\right)$ in comparison to the Langmuir model $\left(R^{2}=0.9802\right)$, indicating that the process preferably occurs through physisorption [52]. However, as shown in Figure 7, the adsorption on materials modified with transition metals better fit the Langmuir model $\left(R^{2}>0.98\right)$, suggesting that the physisorption mechanism was preferably substituted by chemisorption [26].

The values of parameter $\mathrm{n}$ in the Freundlich isotherm are higher than 1 for all adsorbents, indicating favorable adsorption. The Temkin model $\left(R^{2}<0.93\right)$ could be used to describe the experimental data. D-R model $\left(R^{2}<0.47\right)$ was not able to fit the S-compounds adsorption processes performed in this work.

For the Langmuir isotherm, $\mathrm{R}_{\mathrm{L}}$ reached values between 0 and 1 (Figure 8), indicating that the sulfur adsorption is favorable. The maximum adsorption capacity of S-compounds $\left(q_{m}\right)$ for this model, in $\mathrm{mg} / \mathrm{g}$, was estimated in the following descending order: $\mathrm{AgNO}_{3} / \mathrm{MCM}-41^{\mathrm{M}}>\mathrm{Ag}_{2} \mathrm{O} / \mathrm{MCM}-41^{\mathrm{M}}>$ $\mathrm{Ni}\left(\mathrm{NO}_{3}\right)_{2} / \mathrm{MCM}-4^{\mathrm{M}}>\mathrm{NiO} / \mathrm{MCM}-41^{\mathrm{M}}>\mathrm{MCM}-41^{\mathrm{M}}$. This result is a clue that $\mathrm{AgNO}_{3} / \mathrm{MCM}-41^{\mathrm{M}}$ was able to promote the best adsorption performance among the tested adsorbents, considering the same study conditions. MCM- $41^{\mathrm{M}}$ modification with $\mathrm{Ag}$ species from $\mathrm{AgNO}_{3}$ can offer a high quantity of new active sites over the silica surface to chemically interact with sulfur compounds [53].

The adsorption equilibrium results of the materials synthesized from commercial silica are shown in Table 4 and Figure $7 \mathrm{f}-\mathrm{h}$. As expected, the experimental sulfur adsorption data of pure $\mathrm{MCM}-41^{\mathrm{C}}$ were better fitted to the Freundlich model, and the results of the samples impregnated with non-calcined salts were better described by the Langmuir mathematical model. $\mathrm{AgNO}_{3} / \mathrm{MCM}-41^{\mathrm{C}}$ synthesized from commercial silica obtained the highest maximum adsorptive capacity among them $\left(\mathrm{q}_{\mathrm{m}}=15.41 \mathrm{mg} / \mathrm{g}\right)$, approximately half of the content adsorbed by $\mathrm{AgNO}_{3} / \mathrm{MCM}-41^{\mathrm{M}}$ synthesized from amorphous silica MPI, emphasizing the higher sulfur adsorption efficiency of the renewable material even when compared to other adsorbents applied for desulfurization in the literature (Table S3 of the Supplementary Materials). 

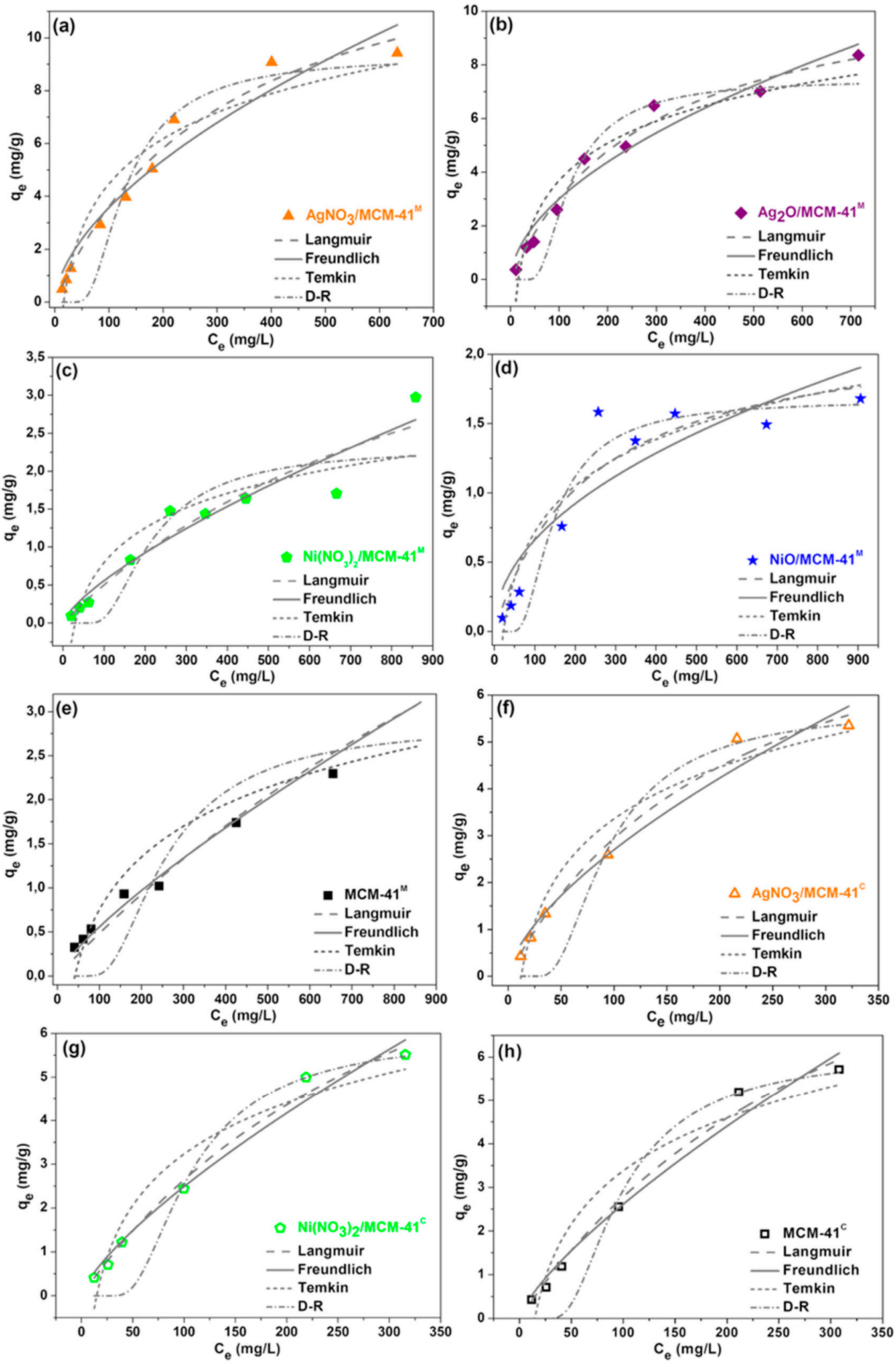

Figure 7. Non-linear adjustments of Langmuir, Freundlich, Temkin and Dubinin-Radushkevich (D-R) equilibrium isotherms of S-compounds adsorption over (a) $\mathrm{AgNO}_{3} / \mathrm{MCM}-41^{\mathrm{M}}$, (b) $\mathrm{Ag}_{2} \mathrm{O} / \mathrm{MCM}-41^{\mathrm{M}}$, (c) Ni( $\left.\mathrm{NO}_{3}\right)_{2} / \mathrm{MCM}-41^{\mathrm{M}}$, (d) NiO/MCM-41 ${ }^{\mathrm{M}}$, (e) $\mathrm{MCM}-41^{\mathrm{M}}$, (f) $\mathrm{AgNO}_{3} / \mathrm{MCM}^{-4} 1^{\mathrm{C}}$, (g) $\mathrm{Ni}\left(\mathrm{NO}_{3}\right)_{2} / \mathrm{MCM}-41^{\mathrm{C}}$ and (h) $\mathrm{MCM}-41^{\mathrm{C}}$. Experimental conditions: room temperature and pressure, real diesel with sulfur concecntration ranging from 25 to $1000 \mathrm{ppm}$. 
Table 4. Parameters and determination coefficients for Langmuir, Freundlich, Temkin and Dubinin-Radushkevich (D-R) isotherm models.

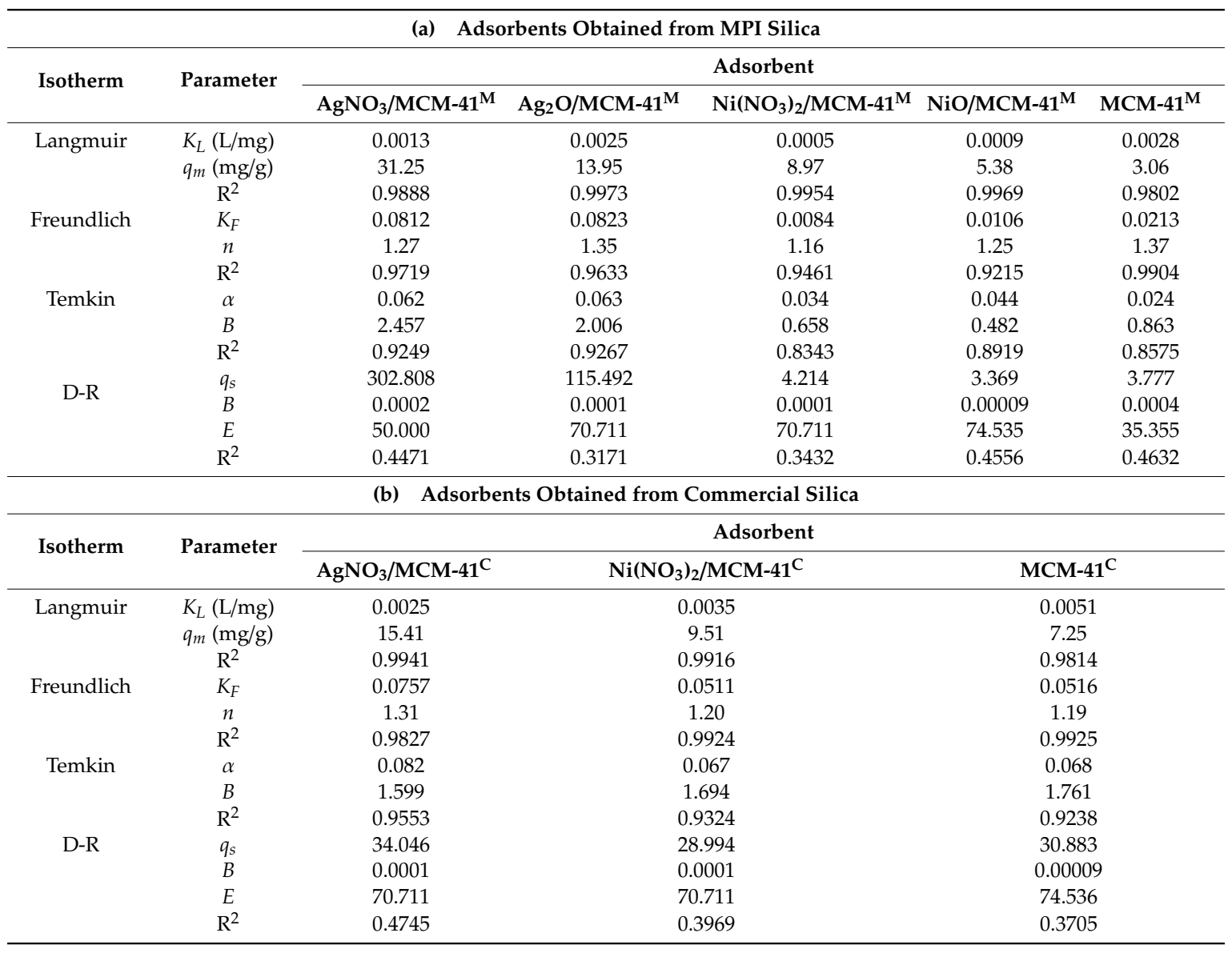

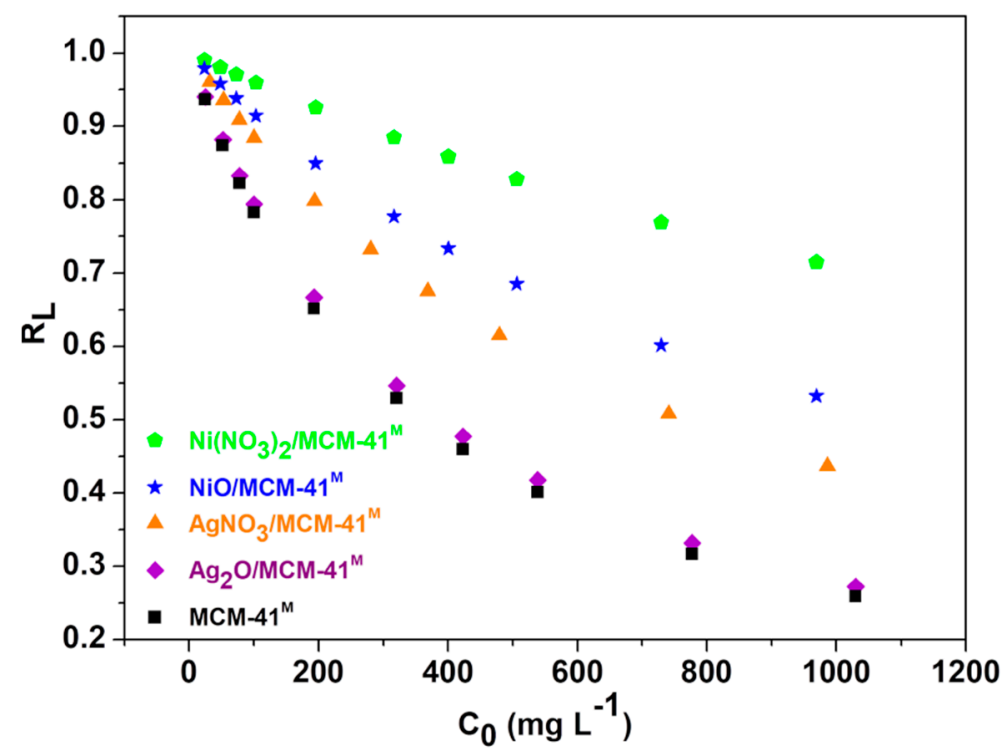

Figure 8. Plots of $\mathrm{R}_{\mathrm{L}}$ versus initial concentrations. 


\subsection{Adsorption Thermodynamics}

A thermodynamic assessment was performed for the sulfur adsorption over the $\mathrm{AgNO}_{3} / \mathrm{MCM}-41^{\mathrm{M}}$ material. The properties observed at 298, 308 and $318 \mathrm{~K}$ are given in Table 5. The values of $\Delta \mathrm{H}^{\circ}$ and $\Delta \mathrm{S}^{\circ}$ can be obtained from the slope and intercept of Van't Hoff plot of $\ln \left(\mathrm{K}_{\mathrm{L}}\right)$ against the reciprocal of $\mathrm{T}$ $\left(1 / T, K^{-1}\right)$ (Figure 9). The Langmuir model fitting for sulfur adsorption results with this material at 298, 308 and $318 \mathrm{~K}$ is depicted in Figure S4 of the Supplementary Materials.

Table 5. Thermodynamic parameters for sulfur adsorption on $\mathrm{AgNO}_{3} / \mathrm{MCM}-41^{\mathrm{M}}$. Experimental conditions: room pressure, real diesel with sulfur concentration ranging from 25 to $500 \mathrm{ppm}$.

\begin{tabular}{cccccc}
\hline Adsorbent & $\mathbf{T}(\mathbf{K})$ & $\mathbf{K}_{\mathbf{L}}(\mathbf{L} / \mathbf{g})^{\mathbf{1}}$ & $\left.\mathbf{\Delta G}^{\circ} \mathbf{( k J} / \mathbf{m o l}\right)$ & $\left.\Delta \mathbf{H}^{\circ} \mathbf{( k J} / \mathbf{m o l}\right)$ & $\Delta \mathbf{S}^{\circ}(\mathbf{k J} / \mathbf{K ~} \mathbf{~ m o l})$ \\
\hline & 298 & $1.94 \times 10^{-3}$ & 15.528 & 42.161 & 0.089 \\
$\mathrm{AgNO}_{3} / \mathrm{MCM}^{-41}{ }^{\mathrm{M}}$ & 308 & $3.13 \times 10^{-3}$ & 14.634 & & \\
& 318 & $5.69 \times 10^{-3}$ & 13.740 & & \\
\hline
\end{tabular}

${ }^{1} \mathrm{~K}_{\mathrm{L}}$ is the Langmuir equilibrium constant calculated by the equation $\frac{\mathrm{C}_{e}}{q_{e}}=\frac{C_{e}}{q_{m}}+\frac{1}{q_{m} K_{\mathrm{L}}}$.

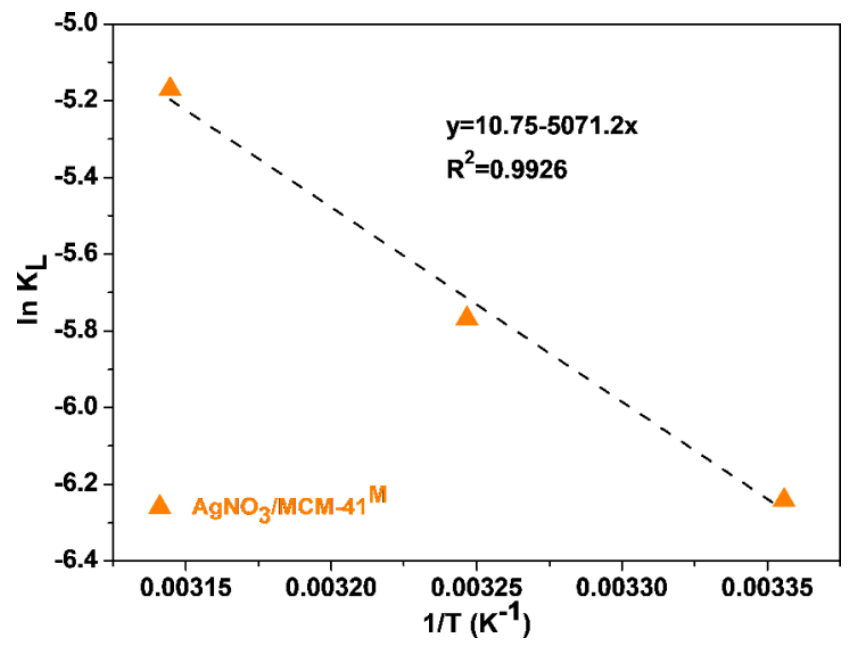

Figure 9. Van't Hoff plot.

The positive value for $\Delta \mathrm{H}^{\circ}$ indicates an endothermic process and its magnitude reaches the region defined for chemisorption in literature $(\geq 40 \mathrm{~kJ} / \mathrm{mol})[54,55]$, thus suggesting predominantly chemical interactions between S-compounds and $\mathrm{AgNO}_{3} / \mathrm{MCM}-41^{\mathrm{M}}$ adsorbent. Although the process is not spontaneous, it can be noticed that there is a tendency of increasing spontaneity by increasing the adsorption temperature, since the total free energy $\left(\Delta \mathrm{G}^{\circ}\right)$ of the system decreases. Finally, the positive entropy $\left(\Delta \mathrm{S}^{\circ}\right)$ confirms the affinity of the adsorbent to S-compounds $[46,56]$.

The data from the kinetic, equilibrium and thermodynamic tests reinforce the results observed in XPS spectra (Figure 5) for $\mathrm{AgNO}_{3} / \mathrm{MCM}-41^{\mathrm{M}}$ and $\mathrm{Ag}_{2} \mathrm{O} / \mathrm{MCM}-41^{\mathrm{M}}$ materials before and after desulfurization, where stable $\mathrm{Ag}_{2} \mathrm{O}$ species apparently did not interact with DBT molecules and only bridging bonds occurred between $\mathrm{Ag}(0)$ sites and the organosulfur rings (Ag-S-R), while active $\mathrm{Ag}-\mathrm{O}$ species and $\mathrm{Ag}(0)$ nanodomains concurrently participate for adsorbing the contaminants via oxidation reactions and bridging interactions via $\pi$-complexation on the non-calcined adsorbent, visibly increasing the process efficiency. The same pattern occurs for Ni-impregnated MCM- $41^{\mathrm{M}}$, where the non-calcined sample presents higher sulfur adsorption capacity than the calcined material; however, their results are not significant in comparison to those obtained with Ag species.

The sulfur adsorption results obtained for the $\mathrm{MCM}-41^{\mathrm{M}}$ and $\mathrm{AgNO} \mathrm{N}_{3} / \mathrm{MCM}-41^{\mathrm{M}}$ materials regenerated by eluting a chloroform/hexane/acetone solution in the 40:30:30 ratio are depicted in Figure 10. Both materials presented a satisfactory reuse rate with just a slight decrease in sulfur 
adsorption after five regeneration cycles, thus indicating that the methodology was successful in removing the adsorbed organosulfurs without compromising their adsorption efficiency.

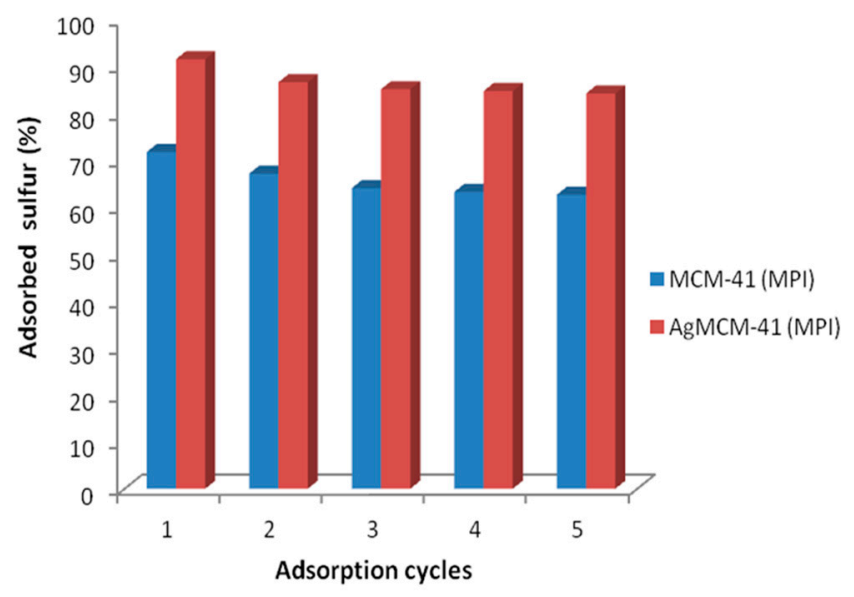

Figure 10. Sulfur adsorption results for the regenerated materials. Experimental conditions: room temperature and pressure.

\section{Materials and Methods}

\subsection{Synthesis}

Amorphous silica (MPI) was synthesized from beach sand following a new methodology described in our previous publication [23]. This silica presents isotherm type III, typical of some porous solids with meso and macroporosity, $33.54 \mathrm{~m}^{2} / \mathrm{g}$ surface area $\left(\mathrm{S}_{\mathrm{BET}}\right), 130.3 \AA$ pore diameter and $0.18 \mathrm{~cm}^{3} / \mathrm{g}$ pore volume. In addition, this material presents a chemical composition of $96.05 \% \mathrm{SiO}_{2}$ and main impurities such as $\mathrm{K}_{2} \mathrm{O}, \mathrm{Fe}_{2} \mathrm{O}_{3}$ and $\mathrm{CaO}$ with average contents of $1.84 \%, 1.12 \%$ and $0.81 \%$, respectively.

MCM-41 was synthesized by the hydrothermal method described in [22,23] using MPI silica, with some modifications. The reaction system was composed of two initial solutions: (I) a mixture containing $14.75 \mathrm{~g}$ of MPI silica, $4.66 \mathrm{~g}$ of sodium hydroxide (PA, Vetec|Sigma-Aldrich, Duque de Caxias, RJ, Brazil) and $105.0 \mathrm{~mL}$ of distillated water, which was stirred for $2 \mathrm{~h}$ at $333 \mathrm{~K}$; and (II) a mixture containing $21.68 \mathrm{~g}$ of cetyltrimethylammonium bromide (CTAB) $(98.0 \%$, Vetec|Sigma-Aldrich, Duque de Caxias, RJ, Brazil) and $105.0 \mathrm{~mL}$ of distillated water, stirred for $1 \mathrm{~h}$ at room temperature. Then, mixture (I) was added to (II) and stirred for $1 \mathrm{~h}$ at room temperature. The final gel had a molar composition of 1.0 CTAB:4.0 SiO $2: 2.0 \mathrm{NaOH}: 200.0 \mathrm{H}_{2} \mathrm{O}$, and was added into a teflon autoclave at $373 \mathrm{~K}$ for $96 \mathrm{~h}$. The $\mathrm{pH}$ was adjusted daily with a 30\% acetic acid (99.8\%, Proquímios, Bangu, RJ, Brazil) solution until achieving a range of 9.5-10.0 $\mathrm{pH}$. Then, the gel was washed with distilled water and $37 \%$ $\mathrm{HCl}$ (PA, Proquímios, Bangu, RJ, Brazil) solution in ethanol (99.5\%, NEON, São Paulo, SP, Brazil) at 2\%. The material was recovered by vacuum filtration and then dried at $393 \mathrm{~K}$ for $2 \mathrm{~h}$. Finally, the solid was calcinated in air flow at $823 \mathrm{~K}$ with $278 \mathrm{~K} / \mathrm{min}$ heating rate for $5 \mathrm{~h}$. MCM-41 was also synthesized with commercial silica (silica gel 60, Macherey-Nagel, Düren, Germany), MCM-41 ${ }^{\mathrm{C}}$, by following the same methodology for comparison with $\mathrm{MCM}-41^{\mathrm{M}}$ in sulfur adsorption tests.

\subsection{Adsorbent Modification}

The mesoporous MCM-41 silica was modified with $\mathrm{Ag}^{+}$and $\mathrm{Ni}^{2+}$ cations from silver nitrate

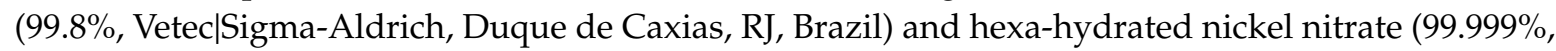
Sigma-Aldrich, St. Louis, MO, USA) salts via wet impregnation. Ethanolic solutions of $\mathrm{AgNO}_{3}$ $(0.03 \mathrm{~mol} / \mathrm{L}$ for $2 \%(w / w)$ and $0.12 \mathrm{~mol} / \mathrm{L}$ for $8 \%(w / w)$ concentrations $)$ and $\mathrm{Ni}\left(\mathrm{NO}_{3}\right)_{2} \cdot 6 \mathrm{H}_{2} \mathrm{O}(0.05 \mathrm{~mol} / \mathrm{L}$ for $2 \%(w / w)$ and 0.22 for $8 \%(w / w))$ salts were prepared and added to $3.0 \mathrm{~g}$ of calcinated MCM- 41 . The functionalizations were performed in rotary evaporators at $120 \mathrm{rpm}$ for $1 \mathrm{~h}$ at room temperature and $3.5 \mathrm{~h}$ under progressive heating $(283 \mathrm{~K} / 30 \mathrm{~min})$ in a water bath until the solvent completely evaporated. 
The modified adsorbents were dried in an oven at $393 \mathrm{~K}$ for $2 \mathrm{~h}$ [57]. Next, $50 \%$ of the material was separated and denominated $\mathrm{AgNO}_{3} / \mathrm{MCM}-41$ and $\mathrm{Ni}\left(\mathrm{NO}_{3}\right)_{2} / \mathrm{MCM}-41$, while the other $50 \%$ was calcinated at $773 \mathrm{~K}$ during $4 \mathrm{~h}$ in an oven at $278 \mathrm{~K} / \mathrm{min}$ heating rate and denominated $\mathrm{Ag}_{2} \mathrm{O} / \mathrm{MCM}-41$ and $\mathrm{NiO} / \mathrm{MCM}-41$.

\subsection{Adsorbent Characterization}

X-ray diffraction analyses (XRD) were performed using a Bruker D2 Phaser (Bruker AXS, Madison, WI, USA) with $\mathrm{CuK} \alpha$ radiation $(\lambda=1.5406 \AA), 30 \mathrm{kV}$ filament, $10 \mathrm{~mA}$ current, Ni filter and a LYNXEYE detector. The XRD patterns were obtained in the range of $1^{\circ}-10^{\circ}$ (low-angle) and $10^{\circ}-90^{\circ}$ (wide-angle) $2 \theta$.

The textural parameters were evaluated via nitrogen adsorption-desorption isotherms at $77 \mathrm{~K}$, as determined by an automatic ASAP 2420 system from Micrometrics (Micrometrics, Norcross, GA, USA). Prior to the measurements, the samples were previously degassed at $473 \mathrm{~K}$ and $10^{-4}$ mbar. The pore size distribution was calculated by applying the Barrett-Joyner-Halenda $(\mathrm{BJH})$ method to the desorption branch of the $\mathrm{N}_{2}$ isotherm.

$\mathrm{MCM}-41^{\mathrm{M}}$ and $\mathrm{AgNO}_{3} / \mathrm{MCM}-41^{\mathrm{M}}$ were evaluated by high-resolution transmission electron microscopy (HRTEM) using a Philips CCCM 200 Supertwin-DX4 microscope. Scanning transmission electron microscopy (STEM) analysis and mapping data were recorded in a Helios Nanolab 650 (FEI, Brno, Czech Republic) instrument with a high-angle annular dark field (HAADF) detector, at $200 \mathrm{kV}$ and $200 \mathrm{nA}$. The microanalysis was carried out with energy dispersive X-ray (EDAX) spectroscopy Super-X system provided with four X-ray detectors and an X-FEG beam.

X-ray photoelectron spectra (XPS) was collected using a Physical Electronics PHI 5700 (Physical Electronic, Minneapolis, MN, USA) spectrometer with non-monochromatic $\mathrm{Al} \mathrm{K \alpha}$ radiation (95.2 W, $15 \mathrm{kV}$, and $1486.6 \mathrm{eV}$ ) and a multi-channel detector. C1s peaks were used as an inner standard calibration peak at $284.8 \mathrm{eV}$. The Multipack software version 9.6.0.15 was used for data analysis. The recorded spectra were fitted using Gaussian-Lorentzian curves to more accurately determine the binding energies of the different element core levels.

\subsection{Real and Model Fuels}

Diesel fuel samples containing 1234.9 ppm (high-sulfur) and $5.1 \mathrm{ppm}$ (low-sulfur) sulfur were kindly donated by the Clara Camarão Potiguar Refinery (Guamaré/RN, Brazil). This material was used for equilibrium, kinetic and thermodynamic evaluation of sulfur adsorption tests performed in a batch system. Moreover, model diesel solutions prepared with dibenzothiophene (98.0\%, Sigma-Aldrich, Co., St. Louis, MO, USA) and n-decane ( $99.0 \%$, Sigma-Aldrich, Co., St. Louis, MO, USA) in a concentration of around $2000 \mathrm{ppm}$ sulfur were used in a set of adsorption tests in fixed bed columns, exclusively for evaluating the composition of the adsorbents after desulfurization via XPS analysis, since real diesel has many interferents in its composition and would generate noisy spectra.

\subsection{Preliminary Adsorption Tests}

All materials prepared in this work were subjected to initial sulfur adsorption tests with real diesel fuel samples (1234.9 ppm sulfur). The tests were performed in adsorption columns $(0.61 \mathrm{~cm} \times 30.0 \mathrm{~cm})$ with downward flow. Each adsorbent was added to the glass columns up to $9.0 \mathrm{~cm}$ in height (about $0.5 \mathrm{~g}$ of material), and a volume of $5.0 \mathrm{~mL}$ of diesel was kept constant during the experiments. The first aliquots $(0.3 \mathrm{~mL})$ were collected and the sulfur content data were recorded using a total sulfur analyzer via ultraviolet fluorescence (UVF) spectrometry (Antek Multitek, PAC, L.P, Houston, TX, USA). 


\subsection{Batch Adsorption}

The adsorptive desulphurization tests were performed using the finite bath method at ambient temperature and pressure. An amount of $0.3 \mathrm{~g}$ of adsorbent and $8.0 \mathrm{~mL}$ of diluted real diesel prepared by a solution of the high and low-sulfur samples were placed in erlenmeyer flasks under constant stirring (100 rpm) in a stirring table (SL 180/DT, Solab, Piracicaba, SP, Brazil). Different proportions of real diesel samples were used to produce the solutions with distinct sulfur concentrations which were applied in each test. The solids were separated by centrifugation and the residual sulfur contents in the liquid phase were collected for quantification following ASTM D5453 methodology. Adsorption effectivity was measured by the UVF sulfur analyzer and the sulfur adsorption capacity per gram of adsorbent at equilibrium $\left(q_{e}\right)$ was calculated using the following expression:

$$
q_{e}=\left(C_{i}-C_{e}\right) V / W
$$

where $V$ is the diesel solution volume (L), $W$ is the adsorbent mass $(\mathrm{g})$ and $C i$ and $C e$ are the initial sulfur content in the fuel $(\mathrm{mg} / \mathrm{L})$ and at equilibrium, respectively.

\subsubsection{Kinetic Tests}

Kinetic tests were performed for MCM- $41^{\mathrm{M}}$ and $\mathrm{AgNO}_{3} / \mathrm{MCM}-41^{\mathrm{M}}$ samples following the methodology described for batch adsorption using a real diesel solution with $500 \mathrm{ppm}$ sulfur content. The supernatant fluid was collected at predetermined times between 5 and $180 \mathrm{~min}$ of stirring. The generated models are used to explain the adsorption mechanism characteristics. Pseudo-first-order (Equation (2)), pseudo-second-order (Equation (3)), Elovich (Equation (4)), intra-particle diffusion (Equation (5)) and the film-diffusion model of Boyd (Equation (6)) were used to analyze the experimental data using the following equations [46]:

$$
\begin{gathered}
\ln \left(q_{e}-q_{t}\right)=\ln q_{e}-k_{1} t \\
\frac{t}{q_{t}}=\frac{1}{k_{2} q_{e}^{2}}+\frac{t}{q_{e}} \\
q_{t}=\frac{1}{\beta} \ln \alpha \beta+\frac{1}{\beta} \ln t \\
q_{t}=k_{i d} t^{\frac{1}{2}}+C \\
F=1-\frac{6}{\pi^{2}} \sum_{n=1}^{\infty} \frac{1}{n^{2}} \exp \left(-n^{2} B_{t}\right)
\end{gathered}
$$

where $q_{t}$ and $q_{e}$ are the amounts of sulfur adsorbed ( $\mathrm{mg} / \mathrm{g}$ ) at time $t(\mathrm{~min})$ and at equilibrium, respectively, $k_{1}$ is the pseudo-first-order constant $\left(\mathrm{min}^{-1}\right), k_{2}$ is the pseudo-second-order adsorption constant $(\mathrm{mg} / \mathrm{g}$ $\mathrm{min})$, the parameter $\alpha$ is the initial adsorption rate of Elovich equation $(\mathrm{mg} / \mathrm{g} \mathrm{min})$ and $\beta$ is the desorption constant $(\mathrm{g} / \mathrm{mg})$ and $k_{i d}$ is the rate constant of the intra-particle diffusion models $(\mathrm{mg} / \mathrm{g}$ $\left.\min ^{1 / 2}\right) . F$ is fractional uptake $\left(q_{t} / q_{e}\right)$ at a certain time and $B_{t}$ is a mathematical function of $F$ calculated by Equations (7) and (8) [58]:

$$
\begin{gathered}
\text { For } F>0.85, B_{t}=f(F)=-0.4977-\ln (1-F) \\
\text { For } F<0.85, B_{t}=f(F)=\left(\sqrt{\pi}-\sqrt{\pi-\sqrt{\frac{\pi^{2} F}{3}}}\right)^{2}
\end{gathered}
$$




\subsubsection{Adsorption Equilibrium Tests}

The evaluation of sulfur adsorption equilibrium was performed in a batch system during $24 \mathrm{~h}$ with samples of real diesel containing sulfur concentrations in the 25-1000 ppm range. Langmuir, Freundlich, Temkin and Dubinin-Radushkevich mathematical models were used to fit the experimental data of sulfur adsorption in order to explain the adsorption on the adsorbent/adsorbate system, as well as predict their equilibrium parameters. The adsorption equilibrium of $\mathrm{MCM}-41^{\mathrm{C}}$ produced from commercial silica and impregnated with non-calcined salts was also evaluated for comparison with the renewable material. The Langmuir model (Equations (9) and (10)) was used to quantify and contrast the performance of various adsorbents [59]:

$$
\begin{aligned}
q_{e} & =\frac{q_{m} K_{L} C_{e}}{1+K_{L} C_{e}} \\
\frac{C_{e}}{q_{e}} & =\frac{1}{q_{m} K_{L}}+\frac{C_{e}}{q_{m}}
\end{aligned}
$$

where $C_{e}(\mathrm{~g} / \mathrm{L})$ and $q_{e}(\mathrm{mg} / \mathrm{g})$ are the equilibrium concentration of the adsorbate and adsorption capacity of the adsorbent, respectively; Langmuir $q_{m}$ is a constant expressing the maximum absorption of the adsorbate $(\mathrm{mg} / \mathrm{g})$ and $K_{L}$ is the Langmuir constant $(\mathrm{L} / \mathrm{g})$, also related to the adsorption energy and the affinity of the adsorbent. Dimensionless constant commonly known as a separation factor $\left(R_{L}\right)$ defined by Weber and Chakravorti (1974) [60], can be given by the following equation:

$$
R_{L}=1 /\left(1+K_{L} C_{0}\right)
$$

where $C_{0}$ in $\mathrm{mg} / \mathrm{L}$ is the initial concentration of the analytes and $K_{L}$ in $\mathrm{L} / \mathrm{mg}$ is Langmuir constant. $R_{L}>$ 1 indicates an unfavorable process, $R_{L}=1$ indicates linearity, $0<R_{L}<1$ indicates a favorable process and $R_{L}=0$ signifies an irreversible adsorption.

The Freundlich model (Equations (12) and (13)) describes non-ideal and reversible adsorption, not being restricted to the formation of a monolayer [61]. This empirical model can be applied to the adsorption of multiple layers, with a non-uniform distribution of adsorption heat and affinities of the heterogeneous surface:

$$
\begin{gathered}
q_{e}=K_{F} C_{e}^{\frac{1}{n}} \\
\ln q_{e}=\ln K_{F}+\frac{1}{n} \ln C_{e}
\end{gathered}
$$

The Freundlich expression is an exponential equation and therefore assumes that the adsorbent concentration in the surface increases with the concentration of adsorbate. With the use of this expression, an infinite amount of adsorption can theoretically occur [62]. The equation is widely used in heterogeneous systems, where $K_{F}(\mathrm{~L} / \mathrm{g})$ and $\mathrm{n}$ are characteristic constants of Freundlich, which indicate the adsorption capacity and adsorption intensity, respectively, where values of $\mathrm{n}$ in the range $1<n<10$ indicate favorable adsorption.

The Temkin isotherm model takes into consideration the effects of indirect adsorbate/adsorbate interactions which suggest that the adsorption heat of all adsorbed molecules in the layer decreases linearly with coverage [47]. The model can be expressed according to Equation (14):

$$
q_{e}=\beta \ln \alpha C_{e}
$$

where $\beta$ is related to the heat of adsorption $(\mathrm{J} / \mathrm{mol})$ and $\alpha$ is the Temkin isotherm constant $(\mathrm{L} / \mathrm{g})$. The Temkin linearized equation is given in Equation (15):

$$
q_{e}=\beta \ln \alpha+\beta \ln C_{e}
$$


The Dubinin-Radushkevich (D-R) isotherm expresses the adsorption mechanism on a heterogeneous and porous surface with variable parameters [63]. The D-R model is described by Equation (16), and the linearized equation is presented in Equation (17):

$$
\begin{gathered}
q_{e}=q_{s} e^{-\beta \varepsilon^{2}} \\
\ln q_{e}=\ln q_{s}-\beta \varepsilon^{2}
\end{gathered}
$$

where $q_{s}$ is the theoretical saturation capacity $(\mathrm{mg} / \mathrm{g}), \beta$ is the D-R constant $\left(\mathrm{mol}^{2} / \mathrm{kJ}^{2}\right)$ and $\varepsilon$ is the Polanyi potential, and can be expressed as follows:

$$
\varepsilon=R \ln \left(1+1 / C_{e}\right)
$$

where $R$ is the universal gas constant $(8.314 \mathrm{~J} / \mathrm{mol} \mathrm{K})$, and $T$ is the absolute temperature (K).

The $\beta$ constant is related to the mean free energy of adsorption which is computed through Equation (19):

$$
E=1 / \sqrt{2 \beta}
$$

where $E$ is the mean adsorption energy $(\mathrm{kJ} / \mathrm{mol})$. The values of $E<40 \mathrm{~kJ} / \mathrm{mol}$ implies physical adsorption while $E>40 \mathrm{~kJ} / \mathrm{mol}$ suggests chemical adsorption [64].

Origin 2018 software (Origin Labs) was used to adjust the linearized equations of the models for calculating the equilibrium parameters.

\subsubsection{Sulfur Adsorption Thermodynamics}

The effect of temperature in S-compounds adsorption was studied by varying the temperature from 298, 308 and $318 \mathrm{~K}$. The obtained thermodynamics parameters describe the variation or the transformation of a system. The standard free energy $\left(\Delta G^{\circ}, \mathrm{kJ} / \mathrm{mol}\right)$, standard enthalpy change $\left(\Delta H^{\circ}, \mathrm{kJ} / \mathrm{mol}\right)$ and standard entropy change $\left(\Delta S^{\circ}, \mathrm{kJ} / \mathrm{mol} \mathrm{K}\right)$ can be calculated from the following Equations [54]:

$$
\begin{gathered}
\Delta G^{\circ}=-R T \ln \left(K_{L}\right)=\Delta H^{\circ}-T \Delta S^{\circ} \\
\ln \left(K_{L}\right)=-\frac{\Delta H^{\circ}}{R T}+\frac{\Delta S^{\circ}}{R}
\end{gathered}
$$

where $K_{L}$ is the Langmuir isotherm constant, $R$ is the gas constant $(8.314 \mathrm{~J} / \mathrm{K} \mathrm{mol})$ and $T$ is temperature in Kelvin.

\subsubsection{Regeneration Tests}

The regeneration methodology consisted of packing $1 \mathrm{~g}$ of residual adsorbent collected from the sulfur adsorption tests in a column with $\sim 10 \mathrm{~mm}$ diameter and $50 \mathrm{~cm}$ length, forming a fixed bed with about $8 \mathrm{~cm}$ adsorbent. Next, $25 \mathrm{~mL}$ of a chloroform/hexane/acetone solution in a ratio of 40:30:30 (chosen after some preliminary tests using various proportions) at $323 \mathrm{~K}$ were added to the column. When the entire solution was completely eluted, the washed adsorbent was heated to $343 \mathrm{~K}$ in a rotary evaporator for $1 \mathrm{~h}$ to evaporate the solvent residue and replaced in a column for a new adsorption test. This evaluation was repeated for 5 regeneration cycles. A process flow diagram of the overall methodology is presented in Scheme 1. 
Step 1: Extraction of MPI silica and synthesis of MCM-41

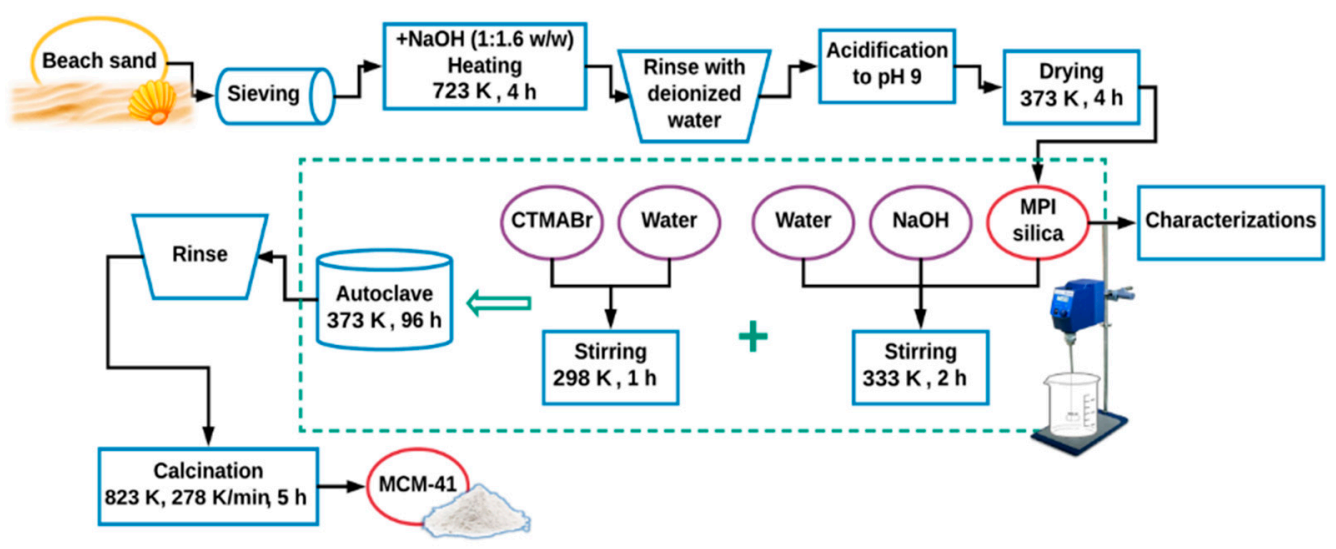

Step 2: Impregnation and desulfurization tests

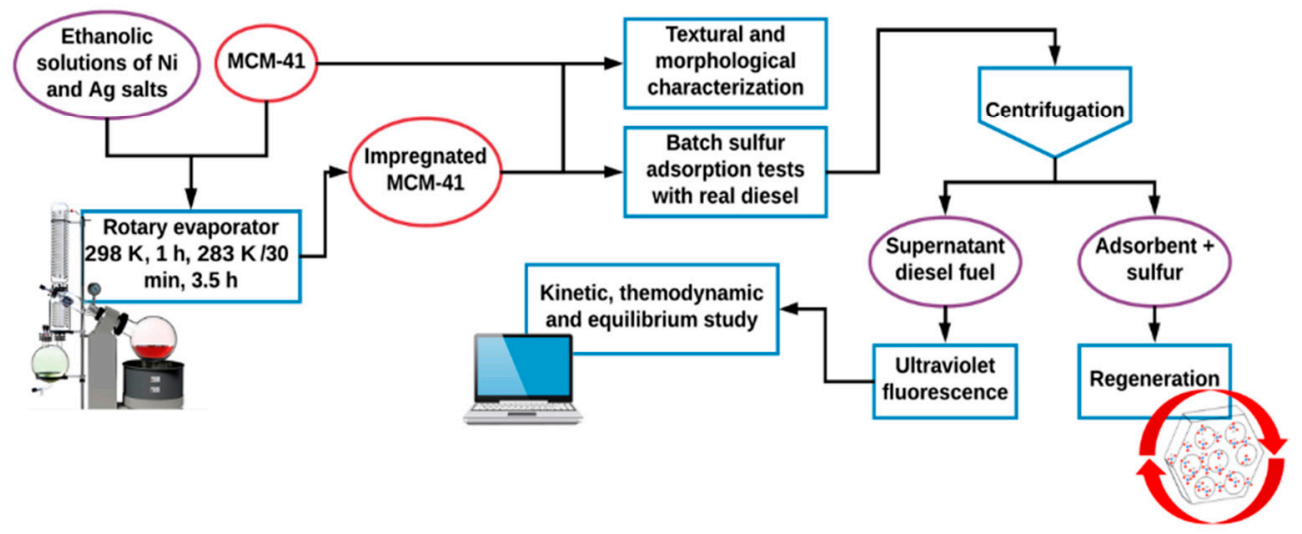

Scheme 1. Process flow diagram for the methodology used in this work.

\section{Conclusions}

The MCM- $41^{\mathrm{M}}$ adsorbent obtained from MPI silica presented the typical characteristics of this material, and its modification with metallic ions did not alter the material structure. Preliminary desulfurization results indicated better adsorption performance of $\mathrm{AgNO}_{3} / \mathrm{MCM}-41^{\mathrm{M}}$ and $\mathrm{Ag}_{2} \mathrm{O} / \mathrm{MCM}-41^{\mathrm{M}}$ samples in comparison to the Ni-impregnated materials. High-resolution images of STEM-EDX and XPS spectra showed the presence of highly dispersed Ag on MCM-41 ${ }^{\mathrm{M}}$ support in the forms of $\mathrm{Ag}(0)$ nanoparticles and active $\mathrm{Ag}-\mathrm{O}$ species, which were able to interact with organosulfur rings via oxidation and $\pi$-complexation in the non-calcined adsorbent $\left(\mathrm{AgNO}_{3} / \mathrm{MCM}-41^{\mathrm{M}}\right)$.

The results from the kinetic, equilibrium and thermodynamic tests reinforced the phenomena observed in XPS data and suggest that the chemisorptive interaction between organosulfur compounds and active Ag nanosites controls sulfur adsorption. The maximum adsorption capacity calculated by the Langmuir equation was about ten times higher in comparison to pure $\mathrm{MCM}-41^{\mathrm{M}}$ and double the $q_{m}$ for the $\mathrm{AgNO}_{3} / \mathrm{MCM}-41^{\mathrm{C}}$ sample from commercial silica. Thus, the $\mathrm{AgNO}_{3} / \mathrm{MCM}-41^{\mathrm{M}}$ material synthesized from MPI silica presents significant efficiency for adsorptive desulfurization and can be used as a complementary process to the expensive HDS method for its low-cost, sustainability and efficient removal of recalcitrant organosulfur compounds. Furthermore, the adsorbents presented a satisfactory regeneration rate by using a chloroform/hexane/acetone mixture (40:30:30 ratio) after a total of five sulfur adsorption cycles. This allows for efficient reuse of this material with certain longevity, ensuring even more reduction in operating costs.

Supplementary Materials: The following are available online at http://www.mdpi.com/2073-4344/9/8/651/s1, Figure S1: Results for preliminary sulfur adsorption tests, Figure S2: XRD results for the adsorbents with $8 \%$ metal, 
Figure S3: Langmuir model fitting for sulfur adsorption results over $\mathrm{AgNO}_{3} / \mathrm{MCM}-41^{\mathrm{M}}$ material at different temperatures, Table S1: Sulfur compound distribution in a straight run diesel oil sample (Hua et al., 2003), Table S2: Critical diameter data for the main aromatic organosulfurs in real diesel, Table S3: Sulfur adsorption performance of some materials studied in literature for comparison.

Author Contributions: Conceptualization, R.V.S. and L.S.d.C.; methodology, R.V.S., A.B.F.C. and J.A.B.S.; formal analysis, E.R.-C., L.M.A.C., M.M.U. and S.B.C.P.; investigation, R.V.S., L.S.d.C., H.O.M.A.M., and A.B.F.C.; resources, L.M.A.C., J.A.B.S. and T.C.B.; data curation, E.R.-C. and S.B.C.P.; writing-original draft preparation, R.V.S., H.O.M.A.M., A.B.F.C., J.A.B.S. and L.S.d.C.; writing-review and editing, R.V.S., H.O.M.A.M., A.B.F.C., E.R.-C. and L.S.d.C.; supervision, R.V.S. and L.S.d.C.; project administration, L.S.d.C.; funding acquisition, S.B.C.P. and E.R.-C.

Funding: This research was funded by the Coordenação de Aperfeiçoamento de Pessoal de Nível Superior (CAPES-Brazil), grant number 001.

Acknowledgments: The authors thank the Energetic Technologies Laboratory (LTEN) and the Clara Camarão Potiguar Refinery (RPCC-Petrobras) for the diesel samples. The authors thank the Coordenação de Aperfeiçoamento de Pessoal de Nivel Superior (CAPES-Brazil). ERC thanks to Ministerio de Ciencia, Innovación y Universidades, Project RTI2018-099668-B-C22 and FEDER funds.

Conflicts of Interest: The authors declare no conflict of interest.

\section{References}

1. Saleh, T.A.; Sulaiman, K.O.; AL-Hammadi, S.A.; Dafalla, H.; Danmaliki, G.I. Adsorptive desulfurization of thiophene, benzothiophene and dibenzothiophene over activated carbon manganese oxide nanocomposite: With column system evaluation. J. Clean. Prod. 2017, 154, 401-412. [CrossRef]

2. Pouladi, B.; Fanaei, M.A.; Baghmisheh, G. Optimization of oxidative desulfurization of gas condensate via response surface methodology approach. J. Clean. Prod. 2019, 209, 965-977. [CrossRef]

3. Andevary, H.H.; Akbari, A.; Omidkhah, M. High efficient and selective oxidative desulfurization of diesel fuel using dual-function [Omim]FeCl4 as catalyst/extractant. Fuel Process. Technol. 2011, 185, 8-17. [CrossRef]

4. Subhan, F.; Aslam, S.; Yan, Z.; Ikram, M.; Rehman, S. Enhanced desulfurization characteristics of Cu-KIT-6 for thiophene. Microporous Mesoporous Mater. 2014, 199, 108-116. [CrossRef]

5. Yang, D.; Yang, S.; Jiang, Z.; Yu, S.; Zhang, J.; Pan, F.; Cao, X.; Wang, B.; Yang, J. Polydimethyl siloxane-graphene nanosheets hybrid membranes with enhanced pervaporative desulfurization performance. J. Membr. Sci. 2015, 487, 152-161. [CrossRef]

6. Etemadi, N.; Sepahy, A.A.; Mohebali, G.; Yazdian, F.; Omidi, M. Enhancement of bio-desulfurization capability of a newly isolated thermophilic bacterium using starch/iron nanoparticles in a controlled system. Int. J. Biol. Macromol. 2018, 120, 1801-1809. [CrossRef]

7. Song, L.; Duan, Z.; Zhu, L.; Zhou, Y.; Xiang, Y.; Xia, D. Selective functionalization of external and internal surface of MCM-41 for adsorptive desulfurization. J. Porous Mater. 2016, 23, 1181-1187. [CrossRef]

8. Subhan, F.; Aslam, S.; Yan, Z.; Zhen, L.; Ikram, M.; Ullah, R.; Etim, U.J.; Ahmad, A. Ammonia assisted functionalization of cuprous oxide within confined spaces of SBA-15 for adsorptive desulfurization. Chem. Eng. J. 2018, 339, 557-565. [CrossRef]

9. Zhao, Z.; Zuhra, Z.; Qin, L.; Zhou, Y.; Zhang, L.; Tang, F.; Mu, C. Confinement of microporous MOF-74(Ni) within mesoporous $\gamma$-Al2O3 beads for excellent ultra-deep and selective adsorptive desulfurization performance. Fuel Process. Technol. 2018, 176, 276-282. [CrossRef]

10. Aslam, S.; Subhan, F.; Yan, Z.; Xing, W.; Zeng, J.; Liu, Y.; Ikram, M.; Rehman, S.; Ullah, R. Rapid functionalization of as-synthesized KIT-6 with nickel species occluded with template for adsorptive desulfurization. Microporous Mesoporous Mater. 2015, 214, 54-63. [CrossRef]

11. Teymouri, M.; Samadi-Maybodi, A.; Vahid, A.; Miranbeigi, A. Adsorptive desulfurization of low sulfur diesel using palladium containing mesoporous silica synthesized via a novel in-situ approach. Fuel Process. Technol. 2013, 116, 257-264. [CrossRef]

12. Sikarwar, P.; Kumar, U.K.A.; Gosu, V.; Subbaramaiah, V. Catalytic oxidative desulfurization of DBT using green catalyst (Mo/MCM-41) derived from coal fly ash. J. Environ. Chem. Eng. 2018, 6, 1736-1744. [CrossRef]

13. Shokouhimehr, M.; Kim, T.; Jun, S.W.; Shin, K.; Jang, Y.; Kim, B.H.; Kim, J.; Hyeon, T. Magnetically separable carbon nanocomposite catalysts for efficient nitroarene reduction and Suzuki reactions. Appl. Catal. A Gen. 2014, 476, 133-139. [CrossRef] 
14. Ahadi, A.; Rostamnia, S.; Panahi, P.; Wilson, L.D.; Kong, Q.; An, Z.; Shokouhimehr, M. Palladium comprising dicationic bipyridinium supported periodic mesoporous organosilica (PMO): Pd@Bipy-PMO as an efficient hybrid catalyst for Suzuki-Miyaura Cross-Coupling Reaction in Water. Catalysts 2019, 9, 140. [CrossRef]

15. Shokouhimehr, M.; Hong, K.; Lee, T.H.; Moon, C.H.; Hong, S.P.; Zhang, K.; Suh, J.M.; Choi, K.S.; Varma, R.S.; Jang, H.W. Magnetically retrievable nanocomposite adorned with Pd nanocatalysts: Efficient reduction of nitroaromatics in aqueous media. Green Chem. 2018, 20, 3809-3817. [CrossRef]

16. Shokouhimehr, M.; Shin, K.Y.; Lee, J.S.; Hackett, M.J.; Jun, S.W.; Oh, M.H.; Jang, J.; Hyeon, T. Magnetically recyclable core-shell nanocatalysts for efficient heterogeneous oxidation of alcohols. J. Mater. Chem. A 2014, 2, 7593-7599. [CrossRef]

17. Zhang, K.; Suh, J.M.; Choi, J.W.; Jang, H.W.; Shokouhimehr, M.; Varma, R.S. Recent Advances in the Nanocatalyst-Assisted NaBH4 Reduction of Nitroaromatics in Water. ACS Omega 2019, 4, 483-495. [CrossRef] [PubMed]

18. Shokouhimehr, M. Magnetically separable and sustainable nanostructured catalysts for heterogeneous reduction of nitroaromatics. Catalysts 2015, 5, 534-560. [CrossRef]

19. Siriworarat, K.; Deerattrakul, V.; Dittanet, P.; Kongkachuichay, P. Production of methanol from carbon dioxide using palladium-copperzinc loaded on MCM-41: Comparison of catalysts synthesized from flame spray pyrolysis and sol-gel method using silica source from rice husk ash. J. Clean. Prod. 2017, 142, 1234-1243. [CrossRef]

20. Yu, H.; Xue, X.; Huang, D. Synthesis of mesoporous silica materials (MCM-41) from iron ore tailings. Mater. Res. Bull. 2009, 44, 2112-2115. [CrossRef]

21. Sohrabnezhad, S.; Jafarzadeh, A.; Pourahmad, A. Synthesis and characterization of MCM-41 ropes. Mater. Lett. 2018, 212, 16-19. [CrossRef]

22. Santos, L.S.; Silva, J.A.B.; Urbina, M.M.; Silva, E.G.; Andrade, J.C.F.; Silva, V.L. Processo de Produção de Sílica Proveniente da Areia de Praia. BR Patent 1020140252835, 2 August 2016.

23. Carvalho, L.S.; Silva, E.; Andrade, J.C.; Silva, J.A.; Urbina, M.; Nascimento, P.F.; Carvalho, F.; Ruiz, J.A. Low-cost mesoporous adsorbents amines-impregnated for CO2 capture. Adsorption 2015, 21, 597-609. [CrossRef]

24. Dutov, V.V.; Mamontov, G.V.; Zaikovskii, V.I.; Liotta, L.F.; Vodyankina, O.V. Low-temperature CO oxidation over Ag/SiO2 catalysts: Effect of $\mathrm{OH} / \mathrm{Ag}$ ratio. Appl. Catal. B Environ. 2018, 221, 598-609. [CrossRef]

25. Hernández-Maldonado, A.J.; Yang, F.H.; Qi, G.; Yang, R.T. Desulfurization of transportation fuels by $\pi$-complexation sorbents: $\mathrm{Cu}(\mathrm{I})-, \mathrm{Ni}(\mathrm{II})-$, and Zn(II)- zeolites. Appl. Catal. B Environ. 2005, 56, 111-126. [CrossRef]

26. Tang, H.; Li, W.; Zhang, T.; Li, Q.; Xing, J.; Liu, H. Improvement in diesel desulfurization capacity by equilibrium isotherms analysis. Sep. Purif. Technol. 2011, 78, 352-356. [CrossRef]

27. Hu, P.; Amghouz, Z.; Huang, Z.; Xu, F.; Chen, Y.; Tang, X. Surface-confined atomic silver centers catalyzing formaldehyde oxidation. Environ. Sci. Technol. 2015, 49, 2384-2390. [CrossRef] [PubMed]

28. Chen, Y.; Huang, Z.; Zhou, M.; Ma, Z.; Chen, J.; Tang, X. Single silver adatoms on nanostructured manganese oxide surfaces: Boosting oxygen activation for benzene abatement. Environ. Sci. Technol. 2017, 51, 2304-2311. [CrossRef]

29. Santos, V.P.; Pereira, M.F.R.; Órfão, J.J.M.; Figueiredo, J.L. The role of lattice oxygen on the activity of manganese oxides towards the oxidation of volatile organic compounds. Appl. Catal. B Environ. 2010, 99, 353-363. [CrossRef]

30. Losurdo, M.; Bergmair, I.; Dastmalchi, B.; Kim, T.H.; Giangregroio, M.M.; Jiao, W.; Bianco, G.V.; Brown, A.S.; Hingerl, K.; Bruno, G. Graphene as an electron shuttle for silver deoxidation: Removing a key barrier to plasmonics and metamaterials for SERS in the visible. Adv. Funct. Mater. 2014, 24, 1864-1878. [CrossRef]

31. Dutov, V.V.; Mamontov, G.V.; Zaikovskii, V.I.; Vodyankina, O.V. The effect of support pretreatment on activity of $\mathrm{Ag} / \mathrm{SiO} 2$ catalysts in low-temperature CO oxidation. Catal. Today 2016, 278, 150-156. [CrossRef]

32. Padin, J.; Yang, R.T. New sorbents for olefin/paraffin separations by adsorption via $\pi$-complexation: Synthesis and effects of substrates. Chem. Eng. Sci. 2000, 55, 2607-2616. [CrossRef]

33. Beck, J.S.; Vartulli, J.C.; Roth, W.J.; Leonowicz, M.E.; Kresge, C.T.; Schmitt, K.D.; Chu, C.T.W.; Olson, D.H.; Sheppard, E.W.; McCullen, S.B.; et al. A new family of mesoporous molecular sieves prepared with liquid crystal templates. J. Am. Chem. Soc. 1992, 114, 10834-10843. [CrossRef] 
34. Kowalczyk, A.; Borcuch, A.; Michalik, M.; Rutkowska, M.; Gil, B.; Sojka, Z.; Indyka, P.; Chmielarz, L. MCM-41 modified with transition metals by template ion-exchange method as catalysts for selective catalytic oxidation of ammonia to dinitrogen. Microporous Mesoporous Mater. 2017, 240, 9-21. [CrossRef]

35. Qin, J.; Li, B.; Zhang, W.; Lv, W.; Han, C.; Liu, J. Synthesis, characterization and catalytic performance of well-ordered mesoporous Ni-MCM-41 with high nickel content. Microporous Mesoporous Mater. 2015, 208, 181-187. [CrossRef]

36. Sing, K.S.W.; Everett, D.H.; Haul, R.A.W.; Moscou, L.; Pierotti, R.A.; Rouquerol, J.; Siemieniewska, T. Reporting physisorption data for gas/solid systems with special reference to the determination of surface area and porosity. Pure Appl. Chem. 1985, 57, 603-619. [CrossRef]

37. Carraro, P.M.; Blanco, A.A.G.; Soria, F.A.; Lener, G.; Sapag, K.; Eimer, G.A.; Oliva, M.I. Understanding the role of nickel on the hydrogen storage capacity of Ni/MCM-41 materials. Microporous Mesoporous Mater. 2016, 231, 31-39. [CrossRef]

38. Shen, S.; Chen, J.; Koodali, R.T.; Hu, Y.; Xiao, Q.; Zhou, J.; Wang, X.; Guo, L. Activation of MCM-41 mesoporous silica by transition-metal incorporation for photocatalytic hydrogen production. Appl. Catal. B Environ. 2014, 150, 138-146. [CrossRef]

39. Hoflund, G.B.; Weaver, J.F.; Epling, W.S. AgO XPS Spectra. Surf. Sci. Spectra 1995, 3, 163-168. [CrossRef]

40. Huang, Z.; Gu, X.; Cao, Q.; Hu, P.; Hao, J.; Li, J.; Tang, X. Catalytically active single-atom sites fabricated from silver particles. Angew. Chem. 2012, 124, 4274-4279. [CrossRef]

41. Cao, Y.; Dai, W.L.; Deng, J.F. The oxidative dehydrogenation of methanol over a novel Ag/SiO2 catalyst. Appl. Catal. A Gen. 1997, 158, L27-L34. [CrossRef]

42. Yang, R.T. Adsorbents: Fundamentals and Applications; Wiley: Hoboken, NJ, USA, 2003.

43. Battocchio, C.; Meneghini, C.; Fratoddi, I.; Venditti, I.; Russo, M.V.; Aquilanti, G.; Maurizio, C.; Bondino, F.; Matassa, R.; Rossi, M.; et al. Silver nanoparticles stabilized with thiols: A close look at the local chemistry and chemical structure. J. Phys. Chem. C 2012, 116, 19571-19578. [CrossRef]

44. Brobbey, K.J.; Haapanen, J.; Gunell, M.; Toivakka, M.; Mäkelä, J.M.; Eerola, E.; Ali, R.; Saleem, M.R.; Honkanen, S.; Bobacka, J.; et al. Controlled time release and leaching of silver nanoparticles using a thin immobilizing layer of aluminum oxide. Thin Solid Films 2018, 645, 166-172. [CrossRef]

45. Haro, N.K.; Vecchio, P.D.; Marcilio, N.R.; Féris, L.A. Removal of atenolol by adsorption—Study of kinetics and equilibrium. J. Clean. Prod. 2017, 154, 214-219. [CrossRef]

46. Habibi, A.; Belaroui, L.S.; Bengueddach, A.; Galindo, A.L.; Díaz, C.I.S.; Peña, A. Adsorption of metronidazole and spiramycin by an Algerian palygorskite. Effect of modification with tin. Microporous Mesoporous Mater. 2018, 268, 293-302. [CrossRef]

47. Choi, A.E.S.; Roces, S.; Dugos, N.; Arcega, A.; Wan, M. Adsorptive removal of dibenzothiophene sulfone from fuel oil using clay material adsorbents. J. Clean. Prod. 2017, 161, 267-276. [CrossRef]

48. Ho, Y.S.; McKay, G. Pseudo second-order model for sorption process. Process Biochem. 1999, 34, 451-465. [CrossRef]

49. Jeon, H.J.; Ko, C.H.; Kim, S.H.; Kim, J.N. Removal of Refractory Sulfur Compounds in Diesel Using Activated Carbon with Controlled Porosity. Energy Fuels 2009, 23, 2537-2543. [CrossRef]

50. Bu, J.; Loh, G.; Gwie, C.G.; Dewiyanti, S.; Tasrif, M.; Borgna, A. Desulfurization of diesel fuels by selective adsorption on activated carbons: Competitive adsorption of polycyclic aromatic sulfur heterocycles and polycyclic aromatic hydrocarbons. Chem. Eng. J. 2011, 166, 207-217. [CrossRef]

51. Oliveira, M.F.; Silva, M.G.C.; Vieira, M.G.A. Equilibrium and kinetic studies of caffeine adsorption from aqueous solutions on thermally modified Verde-lodo bentonite. Appl. Clay Sci. 2019, 168, 366-373. [CrossRef]

52. Meng, C.; Fang, Y.; Jin, L.; Hu, H. Deep desulfurization of model gasoline by selective adsorption on Ag+/Al-MSU-S. Catal. Today 2010, 149, 138-142. [CrossRef]

53. Muzic, M.; Sertic-Bionda, K.; Gomzi, Z.; Podolski, S.; Telen, S. Study of diesel fuel desulfurization by adsorption. Chem. Eng. Res. Des. 2010, 88, 487-495. [CrossRef]

54. Adelodun, A.A.; Ngila, J.C.; Kim, D.; Jo, Y.M. Isotherm, thermodynamic and kinetic studies of selective CO2 adsorption on chemically modified carbon surfaces. Aerosol Air Qual. Res. 2016, 16, 3312-3329. [CrossRef]

55. Raganati, F.; Alfe, M.; Gargiulo, V.; Chirone, R.; Ammendola, P. Isotherms and thermodynamics of CO2 adsorptionon a novel carbon-magnetite composite sorbent. Chem. Eng. Res. Des. 2018, 134, 540-552. [CrossRef] 
56. Ben-Ali, S.; Jaouali, I.; Souissi-Najar, S.; Ouederni, A. Characterization and adsorption capacity of raw pomegranate peel biosorbent for copper removal. J. Clean. Prod. 2017, 142, 3809-3821. [CrossRef]

57. Sales, R.V.; Moura, H.O.M.A.; Silva, S.R.B.; Souza, M.A.F.; Campos, L.M.A.; Rodriguez-Castellon, E.; Carvalho, L.S. Experimental and theoretical study of adsorptive interactions in diesel fuel desulfurization over Ag/MCM-41 adsorbent. Adsorption 2019, 25, 1-13. [CrossRef]

58. Reichenberg, D. Properties of ion-exchange resins in relation to their structure. III. Kinetics of exchange. J. Am. Chem. Soc. 1953, 75, 589-597. [CrossRef]

59. Langmuir, I. The constitution and fundamental properties of solids and liquids. Part I. Solids. J. Am. Chem. Soc. 1916, 38, 2221-2295. [CrossRef]

60. Weber, T.W.; Chakravorti, R.K. Pore and solid diffusion models for fixed-bed adsorbers. AIChE J. 1974, 20, 228-238. [CrossRef]

61. Freundlich, H. Über die adsorption in Lösungen. Z. Phys. Chem. 1907, 57, 385-470. [CrossRef]

62. Pérez-Marín, A.B.; Zapata, V.M.; Ortuño, J.F.; Aguilar, M.; Sáez, J.; Lloréns, M. Removal of cadmium from aqueous solutions by adsorption onto orange waste. J. Hazard. Mater. B 2007, 139, 122-131. [CrossRef] [PubMed]

63. Dubinin, M. The potential theory of adsorption of gases and vapors for adsorbents with energetically nonuniform surfaces. Chem. Rev. 1960, 60, 235-241. [CrossRef]

64. Al-Anber, M.A. Thermodynamics approach in the adsorption of heavy metals. In Thermodynamics-Interaction Studies—Solids, Liquids and Gases; Moreno-Pirajan, J.C., Ed.; InTech: Rijeka, Croatia, 2011; pp. 737-764.

(C) 2019 by the authors. Licensee MDPI, Basel, Switzerland. This article is an open access article distributed under the terms and conditions of the Creative Commons Attribution (CC BY) license (http://creativecommons.org/licenses/by/4.0/). 